\title{
Tulane
}

\author{
Tulane Economics Working Paper Series
}

\section{Commitment to Equity Assessment (CEQ) A Diagnostic Framework to Assess Governments' Fiscal Policies Handbook}

\author{
Nora Lustig \\ Department of Economics \\ Tulane University \\ New Orleans, LA \\ nlustig@tulane.edu \\ Working Paper 1119 \\ April 2011
}

\begin{abstract}
Fiscal policy can change poverty and inequality substantially or little depending on the governments redistributive effort. We develop a diagnostic framework to assess how aligned fiscal policies are with supporting a minimum living standard and human capital accumulation, as well as reducing inequality. The Commitment to Equity Assessment (CEQ) evaluates efforts based on whether governments: i. collect and allocate enough resources to support a minimum living standard for all; ii. collect and distribute resources equitably; iii. ensure spending is fiscally sustainable and that programs are of good quality and incentive compatible; iv. collect and publish relevant information as well as are subject to independent evaluations. The CEQ relies on inequality, poverty and tax and benefit incidence analyses.
\end{abstract}

Keywords: poverty, inequality, fiscal incidence, social policy, Latin America JEL: H5, H51, H52, H53, O15 


\title{
Commitment to Equity Assessment (CEQ) A Diagnostic Framework to Assess Governments' Fiscal Policies ${ }^{1}$ Handbook
}

\author{
Nora Lustig \\ Samuel Z. Stone Professor of Latin American Economics, Tulane University and \\ Non-resident Senior Fellow at the Center for Global Development and Inter-American Dialogue \\ (First draft October 27, 2010; revised April 24, 2011)
}

\begin{abstract}
Fiscal policy can change poverty and inequality substantially or little depending on the government's redistributive effort. We develop a diagnostic framework to assess how aligned fiscal policies are with supporting a minimum living standard and human capital accumulation, as well as reducing inequality. The Commitment to Equity Assessment (CEQ) evaluates efforts based on whether governments: i. collect and allocate enough resources to support a minimum living standard for all; ii. collect and distribute resources equitably; iii. ensure spending is fiscally sustainable and that programs are of good quality and incentive compatible; iv. collect and publish relevant information as well as are subject to independent evaluations. The CEQ relies on inequality, poverty and tax and benefit incidence analyses.
\end{abstract}

JEL: H5, H51, H52, H53 and O15

\footnotetext{
${ }^{1}$ Developed under the leadership of Nora Lustig, the CEQ is a joint project of the Inter-American Dialogue and Tulane University's Center for Inter-American Policy and Research (CIPR) and Department of Economics. The author is very grateful to Sean Higgins as well as Samantha Greenspun, Mariellen Jewers and Emily Travis for their excellent assistance in the preparation of this document. Earlier drafts received very valuable comments from Carola Pessino and John Scott as well as from Nancy Birdsall, Ludovico Feoli, Francisco Ferreira, Ariel Fiszbein, Peter Hakim, Miguel Jaramillo, Luis F. Lopez-Calva, Mario Marcel, Santiago Levy, Tamara Ortega Goodspeed, Jeffrey Puryear, David Roodman, Jaime Saavedra and other members of the CEQ's Advisory Board. The CEQ has received generous support from the Canadian International Development Agency, the Norwegian Ministry of Foreign Affairs, the United Nations Development Programme's Regional Bureau for Latin America and the Caribbean, and the General Electric Foundation.
} 


\section{Table of Contents}

1. Introduction

2. Commitment to Equity in Latin America: a Long Way to Go

3. Commitment to Equity Assessment (CEQ): Methodological Framework

4. CEQ: Diagnostic Questionnaire

5. CEQ: Indicators and Data Requirements

6. CEQ: Technical Definitions of Variables and Indicators

7. References

Figures and Tables

Figure 1: Inequality by Region, 2004

Figure 2: Poverty by Region, 2005

Figure 3: CEQ: Diagnostic Tree

Figure 4: Definitions of Income Concepts: A Stylized Presentation

Figure 5: Lorenz Curves for Progressive and Regressive Transfers

Table 1: Definitions of Income Concepts

Table 2: Definitions of Progressivity of Taxes and Transfers 


\section{Introduction}

Based on the economics of the welfare state, the Commitment to Equity Assessment (CEQ) is a diagnostic framework to measure and evaluate how aligned government expenditures and taxes are with supporting a minimum living standard and reducing inequality in ways that are broadly consistent with macroeconomic stability, microeconomic efficiency and growth. Inspired by the economics of the welfare state, ${ }^{2}$ CEQ evaluates government efforts in individual countries in terms of the following criteria. Do governments collect and allocate enough resources to support a minimum living standard and human capital accumulation for all? Is the collection and distribution of fiscal resources consistent with eradicating the extreme income and human capital poverty gaps? Do they collect and distribute resources equitably? Do they ensure spending is fiscally sustainable and that programs are incentive compatible? Do they collect and publish relevant information and are they subject to independent evaluations? For each criterion there are quantitative and qualitative indicators derived from poverty and inequality analysis, tax and benefit incidence analysis as well as best practices in macroeconomic management, program and policy design and evaluation, and accountability indicators. ${ }^{3}$

CEQ's main purpose is to inform governments of how their public finances affect their equity goals, recommend practical measures, and enhance accountability and transparency through better data collection and evaluation systems. ${ }^{4}$ In the case of Heavily Indebted Poor Countries (HIPC) and very poor countries more broadly, CEQ contributes to inform donors on the orders of magnitude of resource shortfalls to achieve certain goals (for example, reducing poverty by half and universal coverage of primary education) as well as on the actual use and ability of foreign aid to help achieve these goals. Of course, CEQ can be used for other purposes: for example, participatory budgeting processes and non-governmental social observatories. In the future, CEQ will be used to construct a Commitment to Equity Index to rank countries and monitor their performance over time. ${ }^{5}$

While there has been substantial progress in the methods and approaches to evaluate individual policies and programs, there is really no instrument to evaluate social policy as a system. CEQ has been created to fill that void. CEQ is one of the first frameworks to assess social policy -or, rather, public policy with social equity objectives-comprehensively and to make the assessment comparable across countries.

\footnotetext{
2 See, for example, Musgrave (1957) and Barr (2004).

3 For the limitations of static incidence analysis see, for example, Bergh (2005). Also, see Adema and Ladaique (2005), Atkinson (1983), Bourguignon and Pereira da Silva (2003), Barr (2004), Barros et al. (2009), Birdsall et al. (2008), Breceda et al. (2008), Dilnot et al. (1990), Ferreira and Robalino (2010), Fiszbein et al. (2009), Grosh et al. (2008), Goñi et al. (2008), Kakwani (1977), Lambert (2002), Lora (2006), Morra et al. (2009), Lustig (2000), O’Donnell et al. (2008), Shah (2003), Suits (1977), van de Walle and Nead (1995), World Bank (2000/2001, 2006, 2009b, 2011).

${ }^{4}$ CEQ assesses efforts and not outcomes. CEQ can be viewed as a complement to ongoing initiatives such as the World Bank's biennial Human Opportunity Index (Barros et al., 2009), UNDP's Human Development Index and the UN's MDGs (Millennium Development Goals) Monitoring.

${ }^{5}$ Also a joint initiative of the Inter-American Dialogue and Tulane University's CIPR and Economics Department, the construction of such an index is under way.
} 
This handbook has two main purposes: to present the methodological framework of CEQ and a step-by-step guide to applying it in practice, including precise definitions of the variables used in the assessment. Section 2 highlights the redistributive effort of the state in Latin America. Section 3 outlines the characteristics of the CEQ diagnostic framework. Section 4 presents the diagnostic questionnaire. Section 5 discusses some of the main concepts used in the framework and data requirements. Section 6 includes the technical definitions of variables and indicators to apply CEQ in a specific country.

\section{Commitment to Equity in Latin America: a Long Way to Go}

Latin America is the most unequal region in the world. With a Gini coefficient ${ }^{6}$ of .53, Latin America is 19 percent more unequal than Sub-Saharan Africa, 37 percent more unequal than East Asia, and 65 percent more unequal than developed countries (Figure 1). Latin America's poverty rate $^{7}$ (using the US $\$ 2.50$ a day international poverty line) is 22.1 percent. In contrast, East Asia's poverty rate (50.7 percent) is nearly double Latin America's, and poverty rates in Sub-Saharan Africa (80.5 percent) and South Asia (84.4 percent) are roughly four times higher (Figure 2). This should come as no surprise; Latin America is richer than other regions. Its per capita GDP (adjusted for cost of living) is around two times higher than E ast Asia's and is close to five times that of SubSaharan Africa. ${ }^{8}$ A small percentage of the world's extreme poor live in Latin America; in 2005, the share was approximately 4\%. ${ }^{9}$ In absolute numbers, however, Latin America has around 120 million people living below US $\$ 2.50$, or twice as many as Eastern Europe and Central Asia. ${ }^{10}$ The 16 million living on less than a US\$1.25 a day international poverty line in Brazil and Mexico alone in 2005 was about the same as the entire population of sixteen Least Developed Countries. ${ }^{11}$ Because of its highly unequal distribution of income, Latin America has to grow much faster than other regions to achieve the same reductions in poverty. ${ }^{12}$

\footnotetext{
${ }^{6}$ Named after its proponent, the Gini coefficient is a commonly used indicator to measure inequality. The Gini coefficient is an index that can take values between zero and one (or between zero and 100, if in percent). The closer it is to zero (one), the less (more) unequal the distribution in question. Available Ginis are usually not above .65 or below 20 .

7 The incidence of poverty is measured with the headcount ratio equal to the number of people living below the poverty line divided by the total population. Poverty rates are from Chen and Ravallion (2008 p. 33). Poverty rates are for 2005.

8 All the comparisons here are made using GDP per capita PPP in constant 2005 international \$ from World Bank (2008b).

9 Author's comparisons based on Chen and Ravallion (2008 p. 32 Table 6).

${ }^{10}$ Based on Chen and Ravallion (2008 p. 32 Table 6).

11 Author's calculations based on 2005 population statistics from World Bank (2008b) and 2005 poverty estimates from World Bank (2009a). The Least Developed Countries used for comparison are: Bhutan, Comoros, Djibouti, Equatorial Guinea, Gambia, GuineaBissau, Kiribati, Lesotho, Liberia, Maldives, Mauritania, Samoa, Sao Tome and Principe, Solomon Islands, Timor-Leste, Vanuatu. Information on Least Developed Countries from United Nations Development Policy and Analysis Division (online).

12 Perry et al. (2006 p. 4 Table 1.1); De Ferranti et al. (2004 pp. 26-27); World Bank (2005 pp. 84-85).
} 
Figure 1 - Inequality by Region, 2004

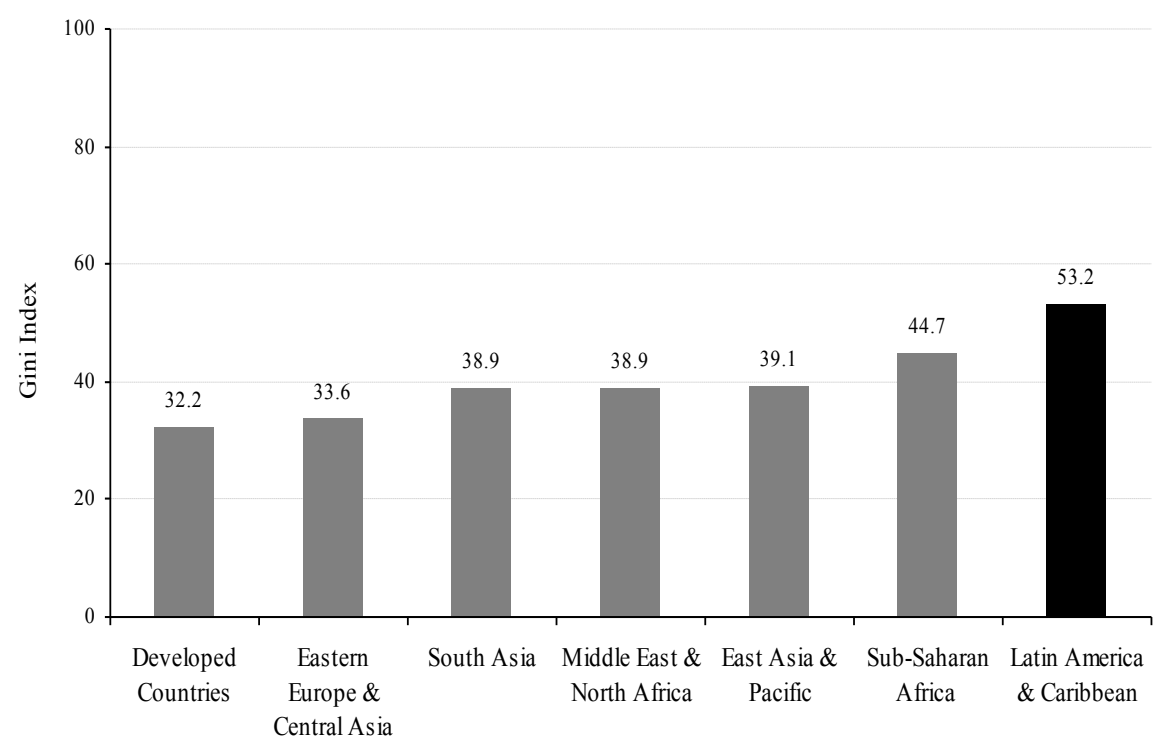

Source: López-Calva and Lustig (2010).

Figure 2 - Poverty by Region, 2005

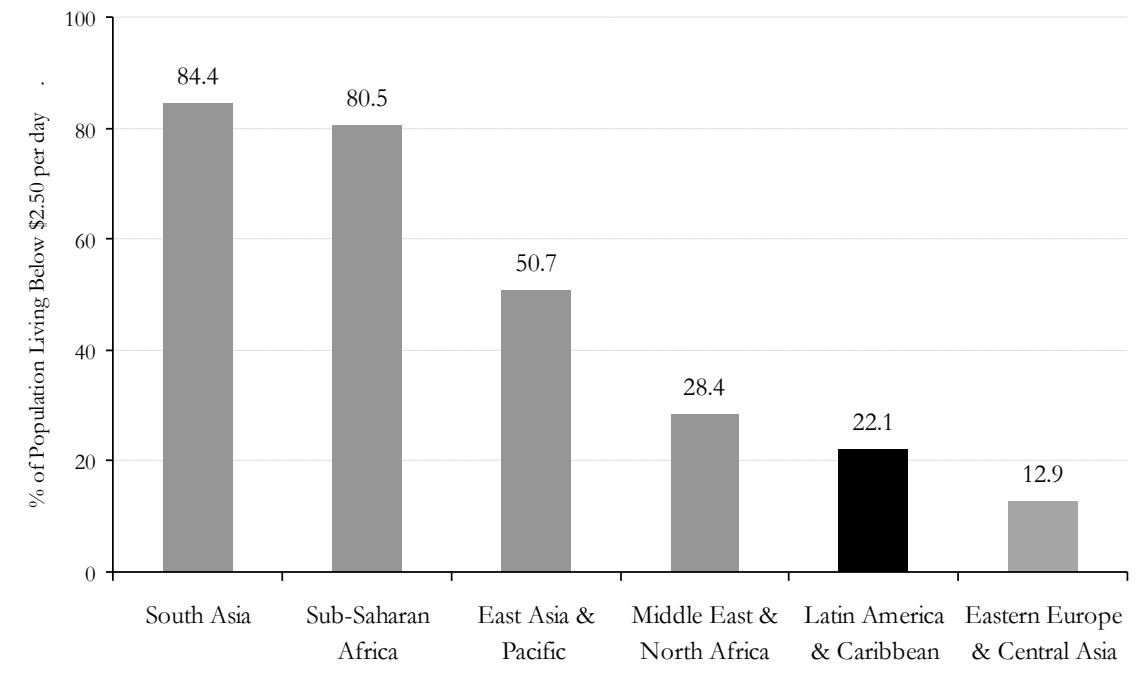

Source: Chen and Ravallion (2008).

One fundamental reason why inequality is high in Latin America is because governments underutilize their power to reduce income inequality through fiscal policy. Fiscal policy can redistribute income directly (through taxes and transfers) and indirectly (mainly through public 
services that build human capital, such as education, health and nutrition). On both fronts, Latin American governments redistribute relatively little.

Before direct taxes and monetary transfers, Latin America's income inequality, ${ }^{13}$ measured by the Gini coefficient, is approximately 13 percent higher than the average before direct taxes and transfers inequality for advanced European countries. In contrast, Latin America's income inequality after taxes and monetary transfers is approximately 60 percent higher than the advanced European countries' after taxes and transfers average. ${ }^{14}$ This is a consequence of two factors. First, most governments in Latin America collect less tax revenues than their European counterparts. ${ }^{15}$ Second, monetary transfers are a smaller share of government spending in Latin America and are not necessarily progressive. ${ }^{16}$ For instance, targeted cash transfers represent a small share of government spending: for example, "while in the United Kingdom per capita cash transfers to the poorest income quintile amount to 6.9 percent of GDP per capita, the average in our Latin American sample equals less than one percent, with the country spending the most - Mexico - transferring only 1.1 percent to the poor." 17

Even if one adds in-kind transfers (that is, government spending on education and health that people consume in the form of free or quasi-free public services), the redistributive impact is still limited. ${ }^{18}$ Incidence analysis finds a fairly flat distribution of social spending across income quintiles in Latin America. ${ }^{19}$ In the case of education, for example, this low redistributive impact of government spending is the consequence of overall education spending that is generally progressive, but highly regressive at the tertiary level. ${ }^{20}$ In health, fairly progressive spending on the noncontributory population is largely offset by contributory systems, where most of the benefits accrue to the non-poor. ${ }^{21}$

\footnotetext{
13 Pre-taxes and monetary transfers income inequality is also sometimes called pre-fiscal inequality.

${ }^{14}$ López and Perry (2008 p. 18-19) and Goñi et al. (2008, p. 5 n.14). Author's calculations based on Goñi et al. (2008 pp. 5-6): The market income Gini for the Latin American countries in the sample was .52, and the disposable income Gini was .5; the market income Gini for European countries in the sample was .46 and the disposable income Gini was .31. This estimate includes monetary transfers and direct taxes only. In-kind transfers and indirect taxes, such as VAT, are not included in the analysis. The comparison should be viewed with certain caution since the market income inequality is quite likely endogenous to the existing transfer systems. If pensions were not generous enough, for example, households which now portray zero or low market incomes would probably have higher levels of market incomes.

15 Organization for Economic Cooperation and Development (OECD) and The Development Centre (2008 p.122).

16 OECD and The Development Centre (2008 p. 60-61); Goñi et al. (2008 p. 18).

${ }^{17}$ Breceda et al., p. 13.

18 Economic Commission for Latin America and the Caribbean (ECLAC) (2007 p. 105-111); OECD and The Development Centre (2008 p. 32-33); López-Calva and Lustig (2010 chapters 4, 5, 6 and 7). See Huber et al. (2006 p. 950-951).

19 See, for example, ECLAC (2007 p. 125), López (2006), Breceda et al. (2008 p. 11).

20 Since the vast majority of students from poor families never reach the tertiary level, the result is a massive subsidy to the middle and upper classes. More than 70 percent of the benefits of public spending on higher education go to the richest 40 percent of the population. Breceda et al.(2008 p.12).

21 Breceda et al. (2008 p.11) write that “...aside from Nicaragua - public health spending is quite pro-rich: on average, the government spends on the poorest income quintile 70 percent of what it spends on the richest quintile. In addition, many Latin American countries have a two-tier health system (usually linked to people's work status) which contrasts [with] the universal health system of the United Kingdom. Accordingly, in Latin America universal health spending declines with people's income, while contributory health spending....strongly increases...."
} 
The good news is that Latin America has made progress in the last decade; in several countries monetary transfers and subsidies as well as in-kind transfers have become more progressive (that is, less regressive). ${ }^{22}$ In Brazil and Mexico, for example, large-scale conditional cash transfers targeted to the poor have reduced post-transfer inequality and poverty. ${ }^{23}$ These programs have demonstrated that redistribution to the poor-even to those in remote areas-is technically feasible. Changes in the composition of public spending in education (towards basic education, for instance) and health (towards preventative care of the uninsured, for instance), have made in-kind transfers more equitable in some countries. ${ }^{24}$ There also have been greater efforts in some countries to bring basic infrastructure (electricity, water, sanitation and sewerage) to the rural poor. ${ }^{25}$

Given these encouraging trends, this is an auspicious time to assess Latin American governments' commitment to foster social equity through fiscal policy. The CEQ can be used to do just that. What follows is a description of this diagnostic tool.

\section{Commitment to Equity Assessment (CEQ): a Methodological Framework}

The first main objective of the welfare state is supporting a minimum living standard. ${ }^{26}$ Supporting a minimum living standard, in turn, entails three goals: i. poverty reduction: that is, ensuring that everyone has a minimum level of consumption; ii. insurance: that is, preventing individuals from falling (or falling further) below the minimum level of consumption due to adverse shocks, both idiosyncratic (unemployment, illness, disability, bad harvests, etc.) and systemic (economic crises, natural disasters, spikes in food prices, etc.); iii. income smoothing: that is, ensuring that a minimum level of consumption is achieved throughout an individual's life-cycle (maternity/paternity leave and retirement, in particular). Welfare states are also concerned with equity. ${ }^{27}$ In particular, welfare states want to equalize opportunities. Thus, the second main objective of the welfare state is supporting a minimum level of human capital accumulation --that is, ensuring that everyone has a minimum level of access to education and healthcare-- especially for the income poor. ${ }^{28}$ Finally, welfare states are also concerned with egregious inequalities; in particular, inequalities arising from market failures, exploitative and predatory behavior or perverse social norms.

\footnotetext{
22 López-Calva and Lustig (2010).

23 See, for example, Barros et al. (2007); Barros et al. in López-Calva and Lustig (2010); Esquivel et al. in López-Calva and Lustig (2010); and Fiszbein and Schady (2009 p.104-107).

${ }^{24}$ For example, these changes are present in Argentina, Brazil, Mexico and Peru in López-Calva and Lustig (2010).

25 Barros et al. (2009 p. 12; 81; 88; 112; 114) highlight changes in policies for basic service provision that have improved access among the rural poor in Brazil, Chile, El Salvador, Mexico, Paraguay and Peru.

26 See, for example, Barr (2004).

27 See, for example, Barr (2004).

28 These dimensions are consistent with poor people's perceptions about poverty and the analytics of the multi-dimensionality of poverty. See, for example, Narayan et al. (2000), World Bank (2000/1) and Alkire and Santos (2010). One could add other dimensions such as building poor people's access to basic infrastructure and/or housing.
} 
Governments can work towards supporting a minimum living standard and reducing inequality through four main channels: taxes and transfers (fiscal policy); ${ }^{29}$ non-budgetary/regulatory interventions; ${ }^{30}$ redistribution of assets; and interventions that change the distribution of voice and power among different groups in society ${ }^{31}$ and alter cultural norms. ${ }^{32}$ Actions in these areas will affect poverty through two main channels: growth and distribution, either by their effect on market (primary) incomes and/or post-fiscal (after net transfers) incomes. CEQ confines its assessment to government efforts in fiscal policy (also called fiscal or budgetary interventions). CEQ uses static incidence analysis; it does not include behavioral responses or general equilibrium effects.

The welfare state not only improves equity but also improves efficiency. For example, transfers can help the credit constrained poor to invest in human capital and thereby result in lower poverty and higher growth. ${ }^{33}$ Directly producing or regulating certain social services can correct market failures in markets where information asymmetries are large (e.g., health care). ${ }^{34}$ However, as economic theory also predicts, state interventions through taxes and transfers can have important efficiency costs. In these instances, there will be a trade-off between efficiency and equity. Fiscal interventions should be such that distortions are kept to a minimum; in particular, the financing and construction of benefits should not result in large negative incentives to labor supply, investment in human capital, saving, fertility, informality and private transfers. CEQ, thus, also assesses whether fiscal interventions are designed and implemented in ways that minimize distortions.

In addition to causing microeconomic distortions, poorly designed or badly implemented fiscal interventions can cause unsustainable macroeconomic imbalances. These imbalances can lead to economic downturns or crises that, in turn, result in large increases in poverty. ${ }^{35}$ That is why tax and transfer policies should avoid cost explosions and unfunded spending commitments. In addition, governments should collect sufficient revenues from sustainable sources (e.g., not rely on occasional windfalls from commodity booms). ${ }^{36} \mathrm{CEQ}$ assesses the extent to which the combination of tax and transfer policy is consistent with the overarching goal of macroeconomic stability.

Finally, the success of fiscal interventions in reducing poverty and inequality requires having the ability to measure progress and having evaluation mechanisms to determine the effectiveness of

\footnotetext{
29 "Taxes" here refer to all government revenues (including "profits" from public sector enterprises); "transfers" refer to current expenditures and includes consumer subsidies. Depending on the country, it may include some producer subsidies, especially in agriculture. More precise definitions will be discussed below.

${ }^{30}$ For example, price controls, minimum wage policies, land reform, import or export restrictions, labor market regulations, and antitrust legislation and competitiveness policies.

31 These include changes in fostering and supporting the mobilization of certain groups (landless peasants, informal workers, unions, women, ethnic minorities, etc.).

32 Examples are campaigns to reduce fertility rates or denounce domestic violence.

33 On the effect of credit constraints on poverty, inequality and growth see Aghion et al.(1997); Aghion and Howitt (1992) and Mookherjee and Ray (2003 and 2006).

34 See Barr (2004).

35 See, for example, Lustig (2000) and Ravallion (2008).

${ }^{36}$ See Birdsall et al. (2008).
} 
fiscal interventions. CEQ assesses the extent to which governments are accountable: that is, whether needed information is produced and shared, whether there are mechanisms to independently validate this information and finally, whether there are mechanisms to independently evaluate the design and implementation of taxes and transfers.

\section{i. $\quad$ Policy Instruments}

In order to assess and quantify the impact of policies and programs, we must identify which redistributive instruments ${ }^{37}$ will be included in the diagnostic tool and organize them in some fashion. There are four main types of redistributive instruments available to governments through fiscal policy: i) taxes on income, consumption and assets; ii) monetary transfers; iii) subsidies to consumption goods, inputs and credit (including tax expenditures); and iv) in-kind transfers through the fully or partially subsidized provision of goods and services particularly in the area of education and health.

Specifically, CEQ will attempt to be as comprehensive as possible in assessing government efforts on both the revenue and spending sides. The menu of policies and programs is vast: direct and indirect taxes (e.g., sales tax and VAT); monetary transfers; subsidies to consumption (e.g., housing, food, fuel and VAT exemptions) and inputs (e.g., fertilizers, improved seeds and credit); in-kind transfers such as national (and sub-national when appropriate) spending in: education including preprimary, primary, lower secondary, (upper) secondary, and tertiary; day care services; early childhood programs; youth programs; scholarships; student credit programs (subsidy component); fee waivers; pensions (subsidized component); health for the insured and uninsured population (subsidized component); housing subsidies; school feeding programs; targeted food subsidies; and rural roads, electricity, water and sanitation in poor regions and neighborhoods. Some of the transfers will take the form of investments (e.g., rural roads, electricity grids, drainage, schools, health facilities, etc.) but almost all are recurrent expenditures (e.g., teachers' and doctors' salaries, educational and medical inputs, etc.). CEQ will quantify and assess the impact of the most significant policies and programs on the income poverty and human capital poverty gaps, and on inequality. ${ }^{38}$

\footnotetext{
37 "Redistributive" here refers to state actions and policies that can potentially result in a more equal distribution of income.

38 Examples of policies: tax systems, public education systems, public health systems, pension systems, price subsidies, price support systems, subsidies to specific sectors (e.g., agriculture), to mention the most important. Examples of programs: conditional or unconditional cash transfer programs; workfare or employment (or employment guarantee) programs; programs to protect poor households from the financial impact of illness, disability or death; programs to provide non-contributory health insurance; programs to prevent people from falling into poverty during old age; programs or policies specifically addressed to building human capital and assets of the poor; early childhood development programs for poor children; programs for pregnant and lactating poor women; programs for poor youth at risk; programs to increase school attendance of the poor (e.g., scholarships, school feeding programs, CCTs); programs to improve the poor's nutrition and health (e.g., food coupons, subsidized basic foodstuffs, nutritional supplements, etc.); programs to improve the poor's access to housing; programs to improve the poor's access to energy (e.g., differential prices); programs to improve the poor's access to credit and private insurance; programs to empower the poor; programs to reduce social exclusion and discrimination; programs to support ethnic minorities; programs to empower women; programs to achieve other socially desirable objectives.
} 


\section{ii. The Design of CEQ}

CEQ consists of a diagnostic framework which helps identify the main causes and constraints (successful fiscal interventions) that prevent a country from achieving (enable a country to achieve) a universal minimum standard of living and reducing inequality in ways that are consistent with macroeconomic and microeconomic efficiency. A diagnostic framework follows a logical sequence to identify or discard factors that may be either obstacles or crucial to achieving a particular objective or essential to understanding a specific phenomenon. Diagnostic exercises usually rely on a combination of predictions from theory, rigorous empirical evidence, practical knowledge and what we call "common sense." The diagnostic approach has been widely used to identify the binding constraints for economic growth. ${ }^{39}$ CEQ is one of the first attempts to apply it to a social equity goal. In broad terms, one would like to know whether a government: i. has enough resources and allocates them well enough to meet social equity policy objectives; ii. has appropriate policies and programs and collects and distributes resources equitably; iii. ensures spending is fiscally responsible and that programs minimize distortions and negative incentives; iv. collects and publishes relevant information, as well as subjects itself to independent evaluations. For simplicity, these criteria are called: resources, equity, quality and accountability and they are defined as follows:

\section{Resources}

- Assess whether government revenues and redistributive spending are potentially sufficient with what would be required for supporting a minimum standard of living. ${ }^{40}$

Equity

- Assess whether the actual level and allocation of redistributive spending as well as the range, design and implementation of programs and policies are consistent with supporting a minimum standard of living.

Quality

- Assess whether the design and implementation of programs and policies ${ }^{41}$ to support a minimum standard of living are broadly consistent with macroeconomic and microeconomic efficiency and whether the programs and policies implemented have high social returns as well as are cost-effective, of high quality and incentive compatible.

\section{Accountability}

- Assess the degree of accountability and transparency with respect to programs and policies designed to support a minimum standard of living.

In sum, CEQ is among the first frameworks to assess social policy -or, rather, public policy with social equity objectives — comprehensively and to make the assessment comparable across countries

\footnotetext{
${ }^{39}$ Hausmann et al. (2006), Rodrik (2007) and Hausmann et al. (2008).

${ }^{40}$ For definitions, see section 6.

41 Throughout this section, "programs" refers to programs designed to support a minimum standard of living and "policies" refers to policies designed to support a minimum standard of living.
} 
and able to be translated into a performance index. CEQ is based on extensive research and expert opinion that give it high content validity. ${ }^{42}$ In particular, the diagnostic framework and indicators for CEQ are selected according to existing analysis of what is constituted as essential to achieving significant reductions in poverty and inequality through fiscal policy. The following sections present the diagnostic framework and questionnaire. Section 6 includes the definitions of variables and indicators.

While CEQ may have some similarities to international benchmarking exercises such as the World Economic Forum's "Global Competitiveness Report"43 and the World Bank's "Doing Business Indicators," 44 there is an important difference. First, it relies on an in-depth tax and benefit incidence analysis rather than on mainly secondary sources and/or perceptions and opinions. Second, international benchmarking exercises such as the Global Competitiveness Index classify as "positives" areas where a country performs better than the average for the reference group and as "negatives" those areas where it underperforms. As noted by Hausmann et al. (2008), however, it is quite possible that over-performance in some areas by a particular country may actually mean underperformance vis-à-vis its own optimal or desirable outcome. In contrast, CEQ is based on a diagnostic framework that allows us to identify the binding constraints (or the crucial contributing factors) to achieving a goal regardless of whether the indicator in question is above or below the average for the group of reference. For example, a government may be allocating a larger share of GDP to redistributive spending than the average for its reference group and yet the amount spent may be insufficient to ensure a minimum living standard for its population. In this case, CEQ will classify it as a "negative" and will attempt a systematic search for the fundamental cause of why, if resources are potentially sufficient, the after net transfers poverty gap is still greater than zero.

\section{iii. Diagnostic Framework}

In order to understand the diagnostic framework, the best is to visualize it as a diagnostic tree as in Figure 3. Let us consider the first objective of the welfare state: supporting a minimum living standard for all. If that objective were met, the disposable income poverty gap ratio measure with an agreed upon extreme poverty line would equal zero. If it is zero, two situations may arise: the market income (income before net transfers) poverty gap ratio is very low to begin with - that is, the country is an equity success story-- or, if it isn't, the state made substantial effort to reduce the poverty gap through fiscal policy. Of course, if a country is already successful, the direct impact of fiscal policy becomes irrelevant (unless it makes things worse). Understanding the causes for this kind of success is very important but CEQ would not be the appropriate instrument. Instead, if the country's success is determined by direct fiscal policy, CEQ will help unveil which specific interventions account for success and why. Likewise, if the government is not successful in

\footnotetext{
42 For more on content validity see Morra Imas and Rist (2009 p. 294); Adcock and Collier (2001).

${ }^{43}$ www.gcr.weforum.org.

${ }^{44}$ www.doingbusiness.org.
} 
supporting a minimum living standard after taxes and transfers, CEQ will help identify the causes of failure and policy actions to improve the government's performance.

Figure 3 - CEQ: Diagnostic Tree

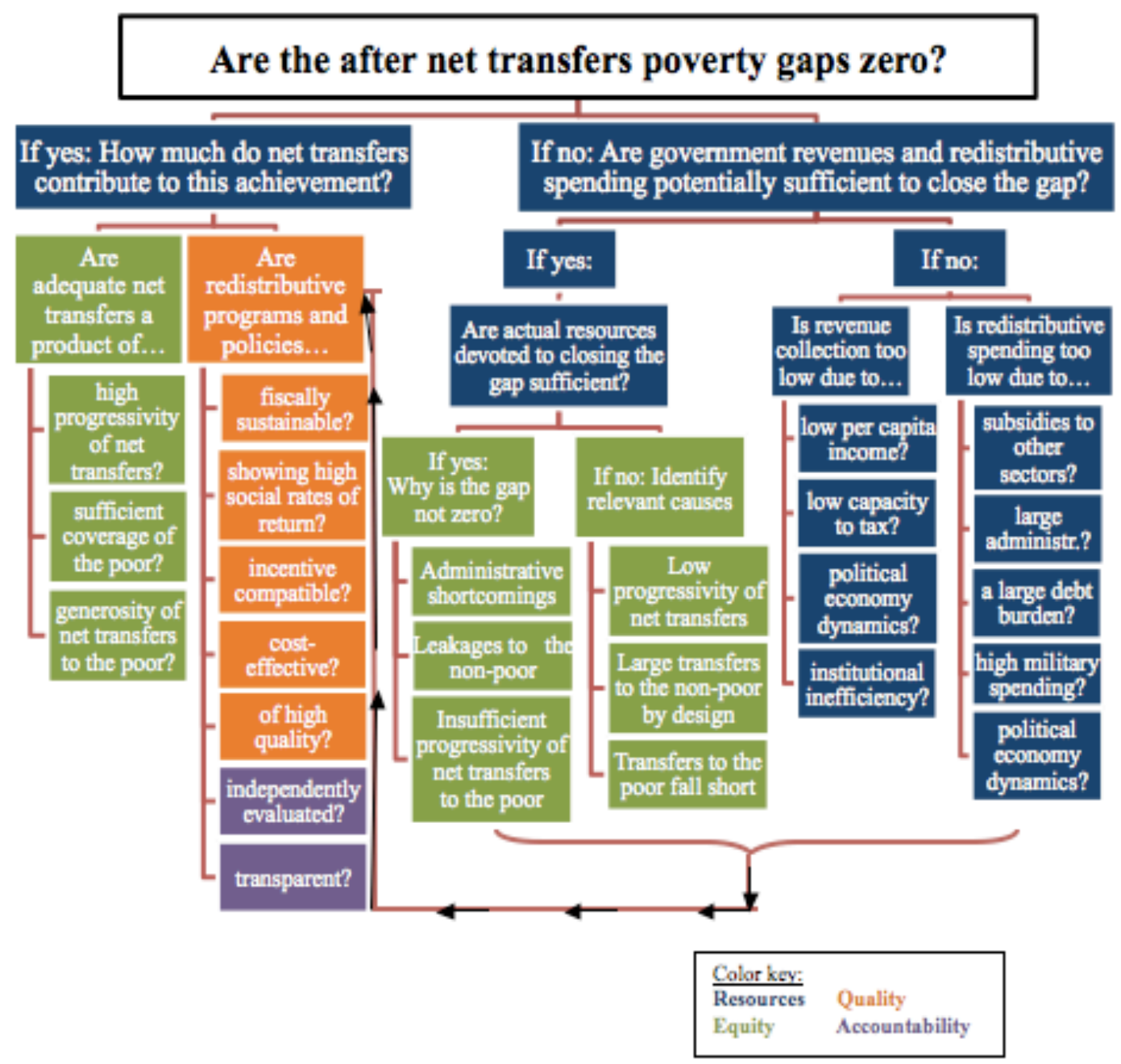

Suppose that, as in most developing countries, the disposable income poverty gap ratio is not zero. There are a number of reasons why that might be the case. In searching for the causes, we follow a logical sequence that will help us to identify the contributing factors and binding constraints. The first reason why the poverty gap is not zero might be that the government either collects too little revenue and/or spends too little for redistributive purposes. We can check that by comparing total revenues and total redistributive spending (defined below) with the before net transfers poverty gap (that is, the poverty gap estimated with market income). If it turns out that either or both are the cause, the next step is to check whether this is so because the country is too poor, the government's 
capacity to tax is too low or public spending is on other items (military expenditures or debt servicing, for example).

In middle-income countries like most of the countries in Latin America, insufficient total fiscal resources or redistributive expenditures are not likely to be a cause for the disposable income poverty gap not being equal to zero. Even if enough resources are spent on redistributive programs and policies, redistributive spending allocated to the poor might not be enough to close the poverty gap. There are at least four -and not mutually exclusive-causes for this. First, redistributive spending is regressive or not progressive enough. Second, regardless of how much is allocated to the non-poor -and, even if what is allocated to the poor is potentially sufficient--, the poverty gap may not be zero because the safety net system does not cover the universe of the poor ${ }^{45}$; third, the per-poor person transfer might be lower than required; fourth, transfers among the poor might not be sufficiently progressive. ${ }^{46}$

In turn, the reasons mentioned above may be the result of several factors. The safety net system may benefit the non-poor or leave out some poor households intentionally. For example, "universal" social security systems often do not include agricultural workers and housekeepers. Cash transfers to the poor exclude households without children, individuals who are below the age of 65, or undocumented migrants. Second, the design of programs may have unintended effects. For example, the participation costs may be too high for the poorest of the poor; or, the eligibility cutoff and amount transferred are not adjusted for differences in prices across regions within a country. Third, in practice the programs may leave out eligible individuals and include non-eligible individuals due to corruption, clientelistic politics or honest mistakes.

In the literature, the share of poor who do not receive benefits of safety net programs are called errors of exclusion and the share of non-poor beneficiaries are called errors of inclusion. However, we consider that it is useful to classify the "errors" of inclusion and exclusion into two groups: intentional and unintended errors of exclusion and inclusion. For simplicity, we shall call the intentional exclusion of the poor and inclusion of the non-poor as exclusion and leakage by design. The unintended errors will be called errors of exclusion and errors of inclusion. The latter could be caused by unintended failures in design or implementation of programs such as higher than anticipated participation costs, deficient information systems, clientelistic politics or corruption, underestimation of geographic isolation, higher than expected administrative costs, unanticipated leakages, lack of accrediting documentation among potential beneficiaries, or self-exclusion, among other factors.

\footnotetext{
45 Transfers could bring a portion of the poor way above the poverty line, for example, and yet leave some of the poor by design.

${ }^{46}$ Of course, another reason may be that direct taxes are not sufficiently progressive.
} 


\section{CEQ: Diagnostic Questionnaire}

Policy Objective: Government makes substantial fiscal efforts to support a minimum standard of living and build the human capital of the poor in ways that reduce overall inequality and are broadly consistent with fiscal sustainability and economic efficiency Criteria: resources, equity, quality and accountability

Step 1: Calculate basic indicators to determine whether goals are achieved (see section 6).

Step 2: After calculating the basic indicators, are the after net transfers income and human capital poverty gaps ${ }^{47}$ (poverty gaps, from now onwards) zero?

If yes: $=>$ proceed to Step 3 .

If no: $=>$ proceed to Step 5.

Step 3: If poverty gaps are zero (i.e., poverty is eradicated), which of the following factors explain this success?

a. High economic growth and/or equitable (pro-poor) economic growth.

b. Fiscal resources are sufficient and equitably collected and distributed. (To comment on this item, complete section E2 below)

Step 4: If the poverty gaps are zero, sections E2-E5 are designed to assess the contribution of the progressivity of net transfers, coverage of the poor, size of net transfers to the poor, and progressivity of net transfers among the poor, respectively, to achieving the goal of closing the poverty gaps. $=>$ Proceed to E2.

Step 5: If the poverty gaps are not zero, is it because total government revenues fall short and/or because the government does not allocate sufficient budgetary resources for redistributive spending purposes? $=>$ Proceed to $\mathbf{R} 1$

\section{RESOURCES: Assess whether government revenues and redistributive spending are potentially ${ }^{48}$ sufficient with what would be required for supporting a minimum standard of living.}

\section{R1. Revenue Collection Effort}

R1.1 Does the government collect sufficient combined resources to close the: $i$. before net transfers income poverty gap (market income poverty gap); ii. before net transfers human

\footnotetext{
${ }^{47}$ For definitions of net transfers poverty gaps see section 6 of this handbook.

${ }^{48}$ For definitions, see Section 6.
} 
capital gap; and, iii. before net transfers overall poverty gap, both in normal times and in the event of systemic shocks? ${ }^{49}$

R1.2 Are total revenues and tax revenues (as a percent of GDP) consistent with the country's GDP per capita? ${ }^{50}$

If the answer to R1.1 is yes, $=>$ proceed to question R2. If not, => proceed to R1.3.

R1.3 Explain why the government does not collect sufficient combined resources to close the i. before net transfers income poverty gap (market income poverty gap); ii. before net transfers human capital gap; and, iii. before net transfers overall poverty gap. Is it due to: ${ }^{51}$

a. Low per capita income?

b. Low capacity to tax/raise revenues? In turn, is the low capacity to tax due to:

i. Political economy dynamics?

ii. Institutional inefficiency?

iii. Other (specify)?

c. Other (specify)?

\section{R2. Redistributive Spending Effort}

R2.1 Does the government allocate sufficient budgetary resources for redistributive spending purposes to potentially close the: $i$. before net transfers income poverty gap (market income poverty gap); ii. before net transfers human capital gap; and, iii. before net transfers overall poverty gap, both in normal times and in the event of systemic shocks?

R2.2 Are total government spending and social spending (as a percent of GDP) consistent with the country's GDP per capita? ${ }^{52}$

If the answer to $\mathrm{R} 2.1$ is yes, $=>$ proceed to Step 7 (Equity section). If not, => proceed to R2.3 and then to Step 6.

R2.3 Explain why the government does not allocate sufficient budgetary resources for redistributive spending purposes to potentially close the: $i$. before net transfers income poverty gap (market income poverty gap); ii. before net transfers human capital gap; and, iii. before net transfers overall poverty gap, both in normal times and in the event of systemic shocks. Is it due to:

\footnotetext{
${ }^{49}$ During systemic shocks a government may choose to use reserves or contingency funds. This should be counted as part of the total resources to smooth the impact of systemic adverse shocks.

50 The answer to this question will depend on benchmarks that can be provided upon request.

51 Throughout the questionnaire, the answers to a question such as "Is it due to...?" should be explained. For example, if political economy dynamics are identified as a cause for low capacity to tax, identify which dynamics and why.

52 The answer to this question will depend on benchmarks that can be provided upon request.
} 

a. Subsidies to other sectors?
b. Overblown administration?
c. A large debt burden?
d. High military spending?
e. Political economy dynamics?
f. Other (specify)?

Step 6: If the poverty gaps are not zero and the government's total fiscal revenue and/or redistributive spending are not sufficient to close the poverty gap, poverty reduction might still be lower than it could be with the given redistributive spending. Sections E2 (progressivity of net transfers), E3 (coverage of the poor by safety net system ${ }^{53}$ ) and E4 (generosity of net transfers to the poor) are designed to identify policy actions that could further reduce poverty even when existing resources are insufficient. => Proceed to E2.

Step 7: If the government allocates sufficient budgetary resources for redistributive spending purposes, why is the poverty gap not zero? There could be several reasons: the share of redistributive spending going to the poor is insufficient; coverage of the poor is not universal; generosity of net transfers to the poor is too low; progressivity of transfers among the poor is too low. $=>$ Proceed to the Equity section.

\section{EQUITY: Assess whether the actual level and allocation of redistributive spending as well as the range, design and implementation of programs and policies are consistent with supporting a minimum standard of living.}

\section{E1. Allocation of Redistributive Spending to the Poor}

E1.1 Is the proportion of redistributive spending allocated to closing the before net transfers poverty gaps (on anti-poverty programs, basic education, basic health care, etc. as specified in public sector budget) sufficient, both in normal times and in the event of systemic shocks?

Step 8: If the goal of closing the poverty gaps is not achieved because the share of redistributive spending allocated to the poor is insufficient, E2 seeks to assess whether net transfers are not sufficiently progressive (in particular, because net transfers to the non-poor are too large). If the goal is not achieved but the share of redistributive spending allocated to the poor is sufficient, E2 seeks to assess the progressivity of the system. In either case, $=>$ proceed to $\mathrm{E} 2$.

\section{E2. Progressivity of Net Transfers}

\footnotetext{
${ }^{53}$ Safety net system here can include redistributive programs not included under social spending.
} 
E2.1 Are net transfers to the non-poor too large? To answer this question, estimate the amount and proportion of net transfers that reach the non-poor (based on household surveys and public sector budget). Is what remains insufficient to close the poverty gap?

E2.2 How equalizing/unequalizing is the distribution of net transfers? To answer this question, calculate the incidence of net transfers for specific programs, ${ }^{54}$ policies, taxes,${ }^{55}$ and overall by: i. quantiles; ${ }^{56}$ ii. poor vs. non-poor; and iii. other groupings. Calculate Suits and Kakwani indices for public spending and revenues; also draw net transfers incidence curves ${ }^{57}$ by quantiles.

a. What is the progressivity of the tax (revenue-raising) system, total government spending, redistributive spending and net transfers overall?

b. What proportion of transfers for specific programs, total monetary transfers, policies (for example, education and health spending) and overall (the sum of all monetary and in-kind transfers) accrues to: $i$. the non-poor; ii. the middle range $;^{58}$ and iii. the richest 20,10, 5, 1 and 0.1 percent? ${ }^{59}$

c. What is the average size of per capita net transfers going to: i. the non-poor; ii. the middle range; and iii. the richest 20,10,5, 1 and 0.1 percent?

d. How much of cash transfers (individually for flagship programs and combined for all cash transfers) goes to i. the bottom $20 \%$ and ii. the bottom $40 \%$ of the income distribution? This should be expressed in absolute terms (the value of transfers in local currency units), as a proportion of total cash transfers, and as a percent of GDP.

e. Which programs and policies are: i. progressive in absolute terms? ii. progressive in relative terms; iii. neutral; iv. regressive?

f. What proportion of total redistributive spending is allocated to programs that are: $\mathrm{i}$. progressive in absolute terms? ii. progressive in relative terms; iii. neutral; iv.

regressive?

g. Are income tax revenues and taxes on wealth (as a percent of GDP) consistent with the country's GDP per capita? ${ }^{60}$

h. What proportion of taxes is paid by: $i$. the non-poor; ii. the middle range; iii. the richest $20,10,5,1$ and 0.1 percent?

\footnotetext{
54 Some surveys do not include questions directly asking about specific program benefits that a household might have received. There are three methods to determine whether a household received transfers from a specific program and quantify the benefits. See the "Definitions" subsection of Technical Definitions of Variables.

55 Indicate whether the tax data is included in the survey or if it must be imputed, and if so, how it is imputed.

${ }^{56}$ Quantiles ideally should be centiles. If that is not feasible, use the smallest feasible quantile (by 5 percent, deciles and quintiles).

57 The benefit/tax incidence curves are analogous to the growth incidence curves but include the change in per capita income before and after net transfers in the y-axis (instead of growth in per capita income between two points in time).

58 The boundaries for middle range should be given by the non-poor that are not in the top 10 percent.

${ }^{59}$ The feasible level of disaggregation will depend on the representativeness of the surveys used for the calculations.

${ }^{60}$ The answer to this question will depend on benchmarks that can be provided upon request.
} 
i. Which taxes and revenue-raising mechanisms are: i. progressive; ii. neutral; iii. regressive in absolute terms; iv. regressive in relative terms?

j. What proportion of taxes/government revenues is: i. progressive; ii. neutral; iii. regressive in absolute terms; iv. regressive in relative terms?

k. Do government spending patterns significantly reduce inequality in access to and quality of services (including inequality between genders, ethnic/racial groups, socioeconomic groups and geographic locations)?

1. What proportion of flagship program and policy beneficiaries is: i. non-poor; ii. middle range; and iii. rich? ${ }^{61}$

m. What proportion of $i$. the non-poor, ii. the middle range and iii. the richest $20,10,5$, 1 and 0.1 percent are flagship program and policy beneficiaries?

n. What impact has each flagship program and policy (individually and combined) had on inequality (as measured by the Gini coefficient)?

o. What is the simulated impact of each flagship program and policy (individually and combined) on inequality (as measured by the Gini coefficient), if there was perfect coverage and no leakages according to the program's eligibility rules?

p. How does the impact of each flagship program and policy (individually and combined) compare to the simulated impact on inequality, assuming perfect coverage and no leakages according to the program's eligibility rules?

q. Which programs and policies have the greatest benefits to the non-poor by design: formal sector insurance schemes, price subsidies, etc.?

r. Which programs and policies have the greatest benefits to the poor by design?

s. Which socioeconomic groups receive the bulk of net transfers going to the non-poor for specific programs, policies, taxes and overall? Possible groups include the near poor, low-income urban workers, corporatist unions, rent-seeking elites, etc.

t. Which socioeconomic groups do not pay their "expected" share of taxes?

E2.3 If the distribution of net transfers is not sufficiently equalizing, is it due to:

a. "Universalistic" welfare systems (by design, everybody has the right to a benefit and hence benefits going to the poor are too small)?

b. State-capture by ruling elites?

c. Distribution rules or patterns among federal and sub-national governments?

d. Other (specify)?

E2.4 Are benefits to the non-poor by design (i.e., intentional), or are there errors of inclusion (i.e., unintended beneficiaries receive benefits)? If there are errors of inclusion, are they due to:

${ }^{61}$ Calculate for the richest 20,10, 5, 1 and 0.1 percent. 
a. Unintended shortcomings in the diagnostic, design, dissemination and/or implementation of existing policies and programs?

b. Clientelistic politics and/or corruption?

c. Shortcomings in targeting mechanisms?

d. Other (specify)?

E2.5 Which programs and policies with large benefits to the non-poor should be kept, and which should be downsized, reformed or eliminated? Why?

\section{Step 9: If redistributive spending allocated to the poor is sufficient to close the poverty gaps, E3 seeks to assess whether poverty gaps are not zero because coverage of the poor is not universal. If redistributive spending allocated to the poor is not sufficient to close the poverty gap, E3 seeks to assess what would happen under the hypothetical situation that resources allocated to the poor were raised to the sufficient level; would the range of existing safety net programs cover the universe of the poor? => Proceed to E3}

\section{E3. Coverage of the Poor}

E3.1 Is coverage sufficient? To answer this question, list all the relevant redistributive programs and policies ${ }^{62}$ (examples listed in footnote and section 6; be sure to include programs that help the poor cope with the effects of systemic shocks such as natural disasters, economic crises, epidemics, rising food and fuel prices, etc.). Then, estimate the following for each program and policy, or at least for the flagship program(s) and main policies (specify which programs and/or policies will be assessed), individually and combined:

a. What is the coverage rate among the poor? Is it close to 100 percent?

b. What is the coverage rate among relevant sub-groups within the poor (women, children, elderly, ethnic minorities, youth at risk, etc.)? Is it close to 100 percent?

\footnotetext{
62 The list should include all relevant policies and programs even if not all of them will be subject to the detailed analysis included in the CEQ. Examples of programs: conditional or unconditional cash transfer programs; workfare or employment (or employment guarantee) programs; programs to protect poor households from the financial impact of illness, disability or death; programs to provide non-contributory health insurance; programs to prevent people from falling into poverty during old age; programs or policies specifically addressed to building human capital and assets of the poor; early childhood development programs for poor children; programs for pregnant and lactating poor women; programs for poor youth at risk; programs to increase school attendance of the poor (e.g., scholarships, school feeding programs, CCTs); programs to improve the poor's nutrition and health (e.g., food coupons, subsidized basic foodstuffs, nutritional supplements, etc.); programs to improve the poor's access to housing; programs to improve the poor's access to energy (e.g., differential prices); programs to improve the poor's access to credit and private insurance; programs to empower the poor; programs to reduce social exclusion and discrimination; programs to support/empower ethnic minorities; programs to empower women; programs to achieve other socially desirable objectives. Examples of policies: tax systems, public education systems, public health systems, pension systems, price subsidies, price support systems, subsidies to specific sectors (e.g., agriculture).
} 
c. If coverage is not close to 100 percent, what are the characteristics of the excluded (after net transfers) poor?

If coverage is close to 100 percent, explain what accounts for this success and proceed to E4. If coverage is not close to 100 percent, proceed to E3.2.

E3.2 If program/policy coverage is not close to 100 percent, what is the cause?

a. Does the combination of programs, safety nets and social policies jointly cover all the groups in need of assistance? For example:

i. The chronic poor.

ii. The transient poor.

iii. Those in danger of falling below the poverty line after a systemic shock.

iv. Those affected by reforms.

v. The vulnerable (pregnant and lactating women, the elderly, youth at risk, etc.).

vi. The socially excluded.

vii. Groups suffering from discrimination.

viii. Other (specify).

b. Do programs and policies leave out some of the poor by design (intentionally)? Who are they (for example, poor households without children or senior citizens, young adults, undocumented migrants, etc.)?

c. Why are poor people left out by design (intentionally)?

i. Political reasons.

ii. To leave out "undeserving" groups.

iii. Discrimination.

iv. To minimize negative incentive effects.

v. To ensure fiscal sustainability.

vi. Fiscal austerity.

vii. Other (specify).

d. Is there a limit to the number of beneficiaries that can enroll in the flagship programs? If so:

i. Is that limit below the total number of eligible households?

ii. Is that limit below the total number of poor households?

iii. Is there a waiting list of eligible households that are not receiving program benefits? If so:

iv. How many households are on the waiting list (in absolute terms, as a proportion of current beneficiaries, and as a proportion of eligible households)?

e. If the poor are left out unintentionally, what explains the errors of exclusion/shortcomings in targeting?

i. Inadvertent gaps in the range of programs and policies.

ii. Unintended shortcomings in the design, dissemination and/or implementation of programs.

iii. Unintentional consequences of rules regarding the distribution of resources among subnational governments. 
iv. Administrative weaknesses.

v. Clientelistic policies and/or corruption.

vi. Geographic isolation of certain poor groups.

vii. Lack of accrediting documentation.

viii. Lack of infrastructure.

ix. Other (specify).

f. Do safety net programs designed to protect the poor during systemic shocks (economic downturns, escalating food prices, natural disasters, etc.) exist? Do programs and policies have the capacity to increase the number of beneficiaries in the event of systemic shocks?

E3.3 Does the government make efforts to increase access of traditionally excluded or discriminated-against groups (afro-descendants, indigenous people, youth at risk, women, etc.) to:
a. Antipoverty programs?
b. Education?
c. Affordable health care?
d. The labor force?
e. Equal pay?
f. High-quality jobs?
g. Other (specify)?

E3.4 What groups are more likely to be poor before and after transfers? ${ }^{63}$ In particular:

i. What groups are more likely to be poor before net transfers?

ii. What groups are more likely to be excluded (or not receive sufficient transfers to escape from poverty) from transfer programs?

E3.5 What impact has each flagship program and policy had (individually and combined) on the headcount index, poverty gap ratio, and squared poverty gap ratio?

a. What is the simulated impact of each flagship program and policy (individually and combined) on the headcount index, poverty gap ratio, and squared poverty gap ratio, if there was perfect coverage and no leakages according to the program's eligibility rules?

b. How does the impact of each flagship program and policy (individually and combined) compare to the simulated impact on the headcount index, poverty gap ratio, and squared poverty gap ratio, assuming perfect coverage and no leakages according to the program's eligibility rules?

c. How does the impact of each flagship program and policy (individually and combined) compare to the potential impact on the headcount index, poverty gap ratio,

${ }^{63}$ The following questions should be analyzed using probit regressions. See Technical Definitions section. 
and squared poverty gap ratio, assuming perfect targeting and complete coverage of the target population?

E3.6 Which policies and programs should be implemented or reformed to increase coverage among the poor? How?

Step 10: If redistributive spending allocated to the poor is sufficient to close the poverty gaps, E4 seeks to assess whether the size of transfers to some of the poor is not large enough to bring them out of poverty. If redistributive spending allocated to the poor is not sufficient to close the poverty gaps, E4 seeks to assess what would happen under the hypothetical situation that resources allocated to the poor were raised to the sufficient level; would the size of transfers to some of the poor remain too small to bring them out of poverty?

\section{E4. Generosity of Net Transfers Among the Poor}

E4.1 Do net transfers per beneficiary to the poor fall short of what is needed to close the poverty gaps? To answer this question, estimate the average net transfers to the poor (per poor person) and the average poverty gap. How do they compare?

If net transfers per beneficiary to the poor do not fall short of what is needed to close the poverty gaps, explain what accounts for this success and proceed to E5. If they do fall short, proceed to E4.2.

E4.2 Does the design of programs and policies intentionally keep net transfers below sufficient levels? If yes, why?

a. Scarcity of resources.

b. To minimize negative incentive effects.

c. To ensure fiscal sustainability.

d. Fiscal Austerity.

e. Other (specify).

E4.3 Do net transfers to the poor fall short due to unintended shortcomings in program and policy allocation rules or budgetary decisions? If so, are they due to:

a. Administrative costs?

b. Rules regarding the distribution of resources among national and subnational governments?

c. Not adjusting the magnitude of transfers in the face of systemic shocks?

d. Other (specify)?

E4.4 Do net transfers fall short because the tax, fees and/or co-payments burden or other factors (such as transportation or labor opportunity costs) on the poor lower the real value of net transfers? 
a. What would the poverty gap be if the poor paid zero direct and indirect taxes, fees and co-payments?

b. Which revenue-raising categories within the tax, fees and co-payments system place the highest burden on the poor?

c. Which revenue-raising categories should be downsized, reformed or eliminated to decrease the tax, fees and co-payments burden on the poor? Why and how?

E4.5 Which policies and programs should be implemented or reformed to increase the size of net transfers to the poor who remain in poverty? Why and how?

Step 11: If redistributive spending allocated to the poor is sufficient to close the poverty gaps, E5 seeks to assess whether the progressivity of transfers among the poor is such that some do not escape poverty. If redistributive spending allocated to the poor is not sufficient to close the poverty gaps, E5 seeks to assess what would happen under the hypothetical situation that resources allocated to the poor were raised to the sufficient level; would the progressivity of transfers still prevent some of the poor from escaping poverty?

\section{E.5 Progressivity of Net Transfers Among the Poor}

E5.1 Are net transfers among the poor sufficiently progressively distributed? In particular:

a. What is the distribution of benefits among the poor? Estimate the squared after net transfers poverty gap ratio, after transfers poverty gaps among the poor by quantile and benefits incidence curves among the poor by quantile.

b. If net transfers among the poor are not sufficiently progressive, is it due to:

i. Administrative weaknesses?

ii. Mistakes in the design, dissemination and/or implementation of existing programs?

iii. Clientelistic policies and/or corruption?

iv. Rules regarding the distribution of resources among national and subnational governments disadvantage areas with the poorest of the poor?

v. The poorest of the poor suffer from systemic shocks more frequently, are hit harder by systemic shocks and/or are more likely to suffer systemic shocks, and the program or policy does not adjust the magnitude of transfers in the face of systemic shocks.

vi. Other (specify)?

E5.2 Are the tax, fees and/or co-payments burdens or other factors (such as transportation or labor opportunity costs) on the poor higher for the poorest of the poor? 
a. What would the squared poverty gap ratio be if the poor paid zero direct and indirect taxes, fees and co-payments? How does this compare with the (after transfers) ${ }^{64}$ squared poverty gap otherwise?

b. Which revenue-raising categories within the tax, fees and co-payments system place a higher burden on the poorest of the poor?

c. Which revenue-raising categories should be downsized, reformed or eliminated to decrease the tax, fees and co-payments burden on the poorest of the poor? Why and how?

E5.3 Which policies and programs should be implemented or reformed to increase the progressivity of net transfers among the poor? Why and how?

\section{Step 12: Proceed to the Quality section.}

\section{QUALITY: Assess whether the design and implementation of programs and policies ${ }^{65}$ to support a minimum standard of living are broadly consistent with macroeconomic and microeconomic efficiency and whether the programs and policies implemented have high social returns as well as are cost-effective, of high quality and incentive compatible.}

\section{Q1. Macroeconomic Efficiency}

Q1.1 Is spending on programs consistent with broader goals of macroeconomic stability and growth? In particular:

a. Are the costs of programs likely to be kept within reasonable bounds and not to become explosive?

b. Are contributory and non-contributory social insurance systems sustainable?

Q1.2 Does the government fund their spending on programs with non-distortionary taxes and not with windfalls from exceptional conditions (commodity price booms, proceeds from privatization, etc.), inflation tax, unsustainable (domestic or external) debt or by cutting resources available for other programs that benefit the poor and vulnerable?

Q1.3 Does the government have fiscal space to implement counter-cyclical policies? If yes, does it use it?

Q1.4 In the face of fiscal austerity, is spending on the poor relatively protected from cuts?

\section{Q2. Microeconomic Efficiency}

\footnotetext{
${ }^{64}$ If an individual program or policy is being analyzed, "after transfers" refers only to the transfers from that program.

${ }^{65}$ Unless specified otherwise, throughout this section, "programs" refers to programs designed to support a minimum standard of living and "policies" refers to policies designed to support a minimum standard of living.
} 
Q2.1 Does the range of anti-poverty programs include those we know have the highest social rates of return (for example, programs which increase the human capital of poor children, reduce the incidence of crime, create local forward and backward linkages, make credit constraints for the poor non-binding, etc.)?

Q2.2 Do the programs' actual social rates of return meet expectations?

Q2.3 Are programs and policies incentive compatible? In particular, are negative incentive effects on labor supply, investment in human capital, saving, fertility, informality, private transfers, migration, etc. small?

Q2.4 Are programs cost-effective? In particular:

a. Are leakages (in terms of beneficiaries and benefits) to non-intended groups small compared with international averages?

b. Are operational costs as a percentage of the total budget within the range of international averages?

Q2.5 Are programs and policies of high quality? In particular:

a. Are independent evaluations of programs positive?

b. Are the results of independent program evaluations used to change the programs' design, implementation and resource allocation (including salaries of service providers)?

c. What is the quality of social services for the poor in relation to the average quality of social services in the country and in relation to international standards?

d. Does the government employ competent staff and pay competitive salaries for the design, implementation and evaluation of antipoverty programs and social services for the poor?

e. Do programs designed to support a minimum standard of living have adequate and clear eligibility criteria and, when applicable, an "exit" strategy?

Q2.6 Are the mechanisms for allocation of resources and selection of beneficiaries sufficiently robust to protect the program from political manipulation and corruption?

a. Does a register of beneficiaries exist that can be audited and evaluated?

b. Does beneficiary selection depend on objective indicators that cannot be manipulated, such as numeric scores (i.e. a means test or proxy means test) or poverty mapping?

c. Is the only justification for removal from the program if conditions are not fulfilled or if the beneficiary is no longer within the target population (for example, a child graduates from school)?

d. Do transparent mechanisms exist to transmit complains and offer suggestions?

e. Can public officials be held accountable by judicial mechanisms? 
Q2.7 Is the tax and subsidy system broadly non-distortionary (in terms of productive and allocative efficiency)?

Q2.8 Are negative incentive effects of the tax system (and other revenue sources) on labor supply, investment in human capital, saving, fertility, informality, private transfers, migration, etc. small?

Q2.9 Is the tax productivity for direct and indirect taxes consistent with OECD standards?

Q2.10 Are negative incentive effects of programs not addressed to the poor (subsidies to industry and agriculture, for example) on labor supply, investment in human capital, saving, fertility, informality, private transfers, migration, etc. small?

\section{Step 13: Proceed to the Accountability section.}

ACCOUNTABILITY: Assess the degree of accountability and transparency with respect to programs and policies designed to support a minimum standard of living.

\section{A1. Evaluation Systems}

A1.1 Does the country have credible mechanisms to do evidence-based program evaluations?

A1.2 Are independent evaluations an administrative or legal requirement of all programs and policies implemented by the government?

A1.3 In the case of in-kind transfers, are there independently validated indicators of quality for government services?

A1.4 Is the tax system subject to independent evaluations to determine the efficiency and equity of various types of taxes?

\section{A2. Adequacy and Transparency of Information Systems}

A2.1 Are the information sources to monitor poverty trends adequate? In particular:

a. Are the coverage, frequency and design of household surveys adequate to make reliable, comparable, national estimates of poverty?

b. Does the government make metadata and microdata from household surveys available?

c. Does metadata comply with the international standard for metadata documentation?

A2.2 Does the country have credible mechanisms for external validation of poverty measures? 
A2.3 Is information to monitor progress on poverty reduction, evaluation methods and evaluation results made available to researchers, policy experts, the business community, civil society and policymakers outside the executive branch?

A2.4 Is information on the cost and budget of public services and programs publicly available? In particular:

a. Is information on the costs (administrative costs in particular) of services and flagship program(s) publicly available?

b. Is information on the (itemized) budget allocated to specific schools, health care facilities, etc. posted in visible places so users can see it?

A2.5 Does the government perform and publish incidence studies? In particular:

a. Does the government collect information to do incidence studies of taxes and government spending, and make the information available?

b. Is it a legal requirement for the government to provide incidence analysis to the legislatures during the budget approval process?

c. Does the government disclose its methods to do incidence analysis to researchers, policy experts, business community, civil society and policymakers outside the executive branch?

d. Does the country have credible mechanisms for external validation of government incidence studies?

A2.6 Does the government make income tax files available in the same way as most advanced OECD countries?

\section{CEQ Indicators and Data Requirements}

In what follows we describe the main concepts used by CEQ. In section 6 we present the technical definition of each variable used in the questionnaire.

Definition of Income Concepts: Market, Disposable, Post-fiscal and Final (Table 1 and Figure 4)

Market income ${ }^{66}$ is defined as earned plus unearned market incomes before government taxes and transfers of any sort. It should include net private transfers, net remittances, and net alimony payments. Total market income equals earned plus unearned market incomes (monetary and nonmonetary) before government taxes and transfers of any sort. It should include net private transfers, net remittances, and net alimony payments AND imputed rent for owner-occupied housing and auto-consumption. Net market income equals market income minus direct taxes and employee contributions to social security. Disposable income equals net market income plus direct monetary

\footnotetext{
${ }^{66}$ Market income is also called primary income.
} 
transfers. Post fiscal income equals disposable income plus indirect subsidies (including indirect tax expenditures) and minus indirect taxes. Final income equals post fiscal income plus in-kind transfers (e.g., imputed value of free or quasi-free government services particularly in education and health), minus in-kind taxes, co-payments in cash or in-kind e.g., when beneficiaries of anti-poverty programs are required to contribute with inputs including labor inputs), user fees and participation costs (transportation costs; opportunity costs).

\section{Table 1 - Definitions of Income Concepts}

\begin{tabular}{|c|c|}
\hline Market Income $=\mathrm{y}^{\mathrm{m}}$ & $\begin{array}{l}\text { Monetary: Earned plus unearned market } \\
\text { incomes before government taxes and transfers } \\
\text { of any sort. It should include net private } \\
\text { transfers, net remittances, and net alimony } \\
\text { payments. } \\
\text { Total: Earned plus unearned market incomes } \\
\text { (monetary and non-monetary) before } \\
\text { government taxes and transfers of any sort. It } \\
\text { should include net private transfers, net } \\
\text { remittances, and net alimony payments AND } \\
\text { imputed rent for owner-occupied housing and } \\
\text { auto-consumption. }\end{array}$ \\
\hline Net Market Income $=y^{n}$ & $\begin{array}{l}\text { Market income } \mathrm{y}^{\mathrm{m}} \text { minus direct taxes and } \\
\text { employee contributions to social security }\end{array}$ \\
\hline Disposable Income $=y^{d}$ & $\begin{array}{l}\text { Net market income } y^{n} \text { plus direct monetary } \\
\text { transfers }\end{array}$ \\
\hline Post-fiscal Income $=y^{\mathrm{pf}^{\mathrm{f}}}$ & $\begin{array}{l}\text { Disposable income } \mathrm{y}^{\mathrm{d}} \text { plus indirect subsidies } \\
\text { (including indirect tax expenditures) minus } \\
\text { indirect taxes }\end{array}$ \\
\hline $\begin{array}{l}\text { Final Income }=y^{\mathrm{f}} \\
\text { or } \\
\text { Final Income }=y^{*^{\mathrm{f}}}\end{array}$ & $\begin{array}{l}\text { Post-fiscal income } \mathrm{y}^{\mathrm{pf}} \text { plus in-kind transfers } \\
\text { minus in-kind taxes, co-payments, user fees and } \\
\text { participation costs. Or, if indirect subsidies and } \\
\text { taxes cannot be imputed, } \mathrm{y}^{\mathrm{f}} \text { equals disposable } \\
\text { income } \mathrm{y}^{\mathrm{d}} \text { plus in-kind transfers minus in-kind } \\
\text { taxes, co-payments, user fees and participation } \\
\text { costs. In the latter case, it will be identified as } \\
\text { Final Income* } \mathrm{y}^{\mathrm{f}}\end{array}$ \\
\hline
\end{tabular}

Source: author's elaboration based on various documents 
Figure 4 - Definitions of Income Concepts: A Stylized Presentation

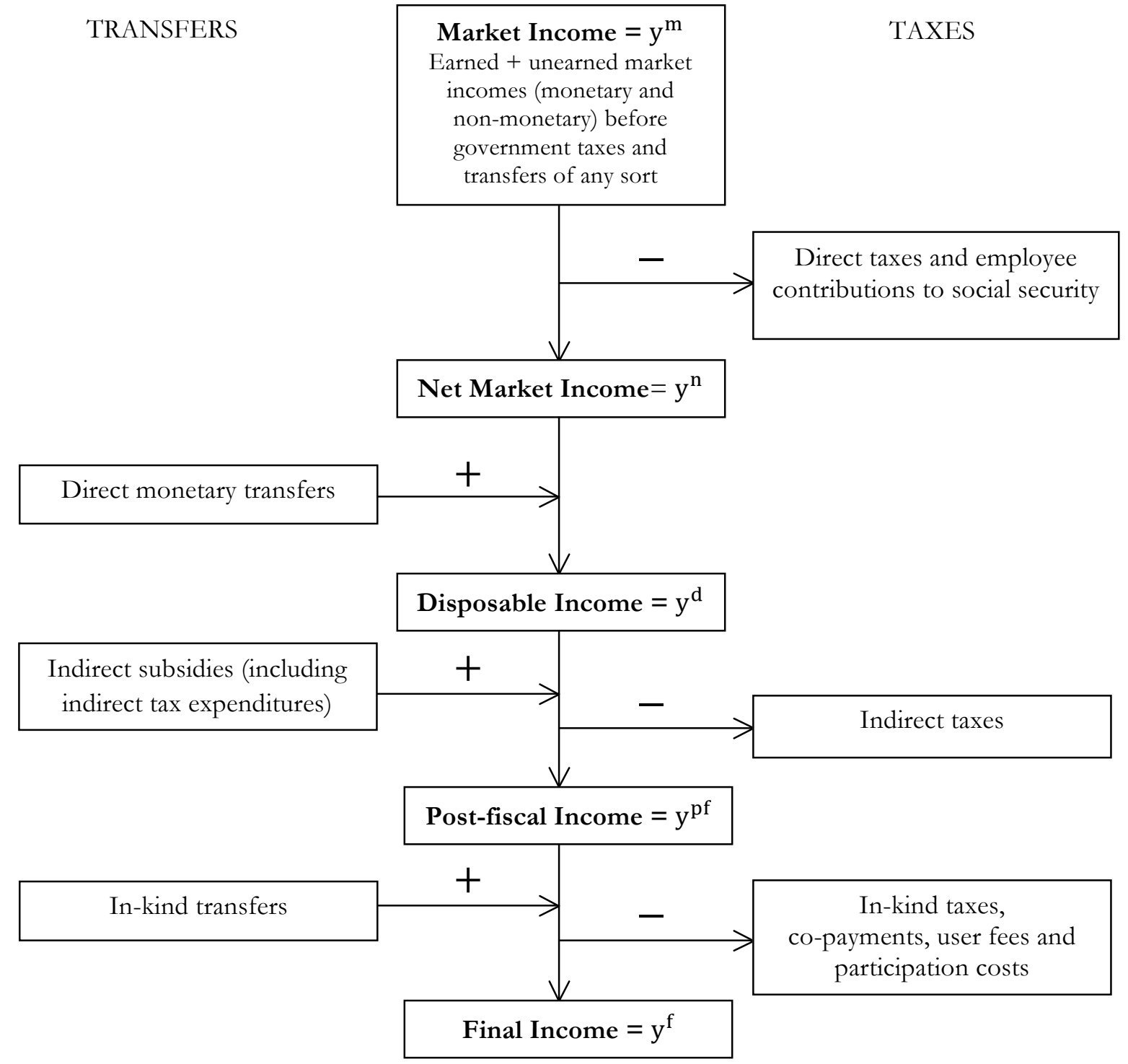

Note: Final Income* will equal Disposable Income plus in-kind transfers and minus in-kind taxes, co-payments, user fees and participation costs. Countries without expenditure surveys will only be able to estimate Final Income*. There are actually two ways that Market Income should be calculated (note that the two different calculations for market income will lead to two different calculations for each definition of income). The two calculations are: 1) Monetary: Earned plus unearned market incomes before government taxes and transfers of any sort. It should include net private transfers, net remittances, and net alimony payments. 2) Total: Earned plus unearned market incomes (monetary and non-monetary) before government taxes and transfers of any sort. It should include net private transfers, net remittances, and net alimony payments AND imputed rent for owner-occupied housing and auto-consumption. 
Data on household market and disposable income can be obtained from standard household surveys (although sometimes there is no information on non-monetary income sources such as autoconsumption). Disposable income is obtained as a combination of available and imputed information depending on how data on income is collected in the surveys. ${ }^{67}$ Indirect subsidies and taxes to calculate post-fiscal income are usually imputed based on consumption data from household surveys (income-expenditure surveys). In-kind transfers are usually imputed based on the reported use of public services by individual households and reported workers' benefits, and the direct average cost of supplying the service based on public expenditures accounts.

\section{Total Government Revenue}

Includes the total budgetary income of the federal government: tax and non-tax revenue plus income generated by direct budgetary controlled entities or public enterprises. In countries where revenue collected at the provincial or state level is important, the total will include the revenues obtained by governments at the subnational level.

\section{Social and Redistributive Spending ${ }^{68}$}

To assess government efforts on the spending side we use social spending from public sector accounts and the concept of redistributive spending. Social spending as commonly defined in official government budgetary classifications and the concept of redistributive spending can be different. Social spending typically includes spending education, health, social security and social assistance. Redistributive spending includes education, health, and social assistance plus indirect consumer subsidies (e.g., food, electricity and gasoline subsidies), some producer subsidies (e.g., agricultural producer subsidies), and "social" tax expenditures (exemption of VAT for some foodstuffs). The information on redistributive spending has to be teased out from public sector accounts at the federal level (and provincial level in the countries where study will include subnational government spending in the analysis). In some countries there is no information on other forms of redistributive spending; in such cases, one should confine the analysis to social spending. ${ }^{69}$

\section{Progressivity and Regressivity: Definitions (Table 2 and Figure 5)}

\footnotetext{
${ }^{67}$ This varies by country. In some countries, household surveys report after direct taxes and social security contributions income only; in other countries, they report it before taxes. The problem is compounded because often wage income is after taxes but the situation of self-employment income is left unclear.

${ }^{68}$ In countries for which the concept of redistributive spending cannot be calculated, studies use social spending. For definition of redistributive spending see section on indicators.

69 Strictly speaking one may also distinguish the subsidized from the non-subsidized portion of social security benefits. Calculations can be done by estimating social and/or redistributive spending with and without the non-subsidized portion of social security benefits.
} 
Since one criterion of the assessment of governments' fiscal interventions is based on the extent of their progressivity, this is a good place to review the definitions used in the literature of what constitutes a progressive tax and progressive transfer system. The most frequently used method to measure the progressivity (or regressivity) of government taxes and transfers is incidence analysis. In essence, incidence analysis consists of comparing the amount of transfers (taxes) received (paid) by population quantiles (usually, deciles or quintiles). Progressivity is measured in absolute terms, comparing transfers or taxes per capita among quantiles; or, it is measured in relative terms, comparing transfers or taxes as a share of each quantile's income. Thus, a transfer will be progressive (regressive) in absolute terms if the poorer one is, the larger (smaller) the size of the transfer one receives in per capita terms; a tax will be progressive (regressive) in absolute terms if the poorer one is, the less (more) one pays in per capita terms. A transfer will be progressive (regressive) in relative terms if the poorer one is, the larger (smaller) the size of the transfer one receives in relation to one's income; a tax will be progressive (regressive) in relative terms if the poorer one is, the less (more) one pays in relation to one's income (Table 2). ${ }^{70}$ The convention in the literature on incidence analysis is to measure equity of transfers in terms of their absolute progressivity and taxes in terms of their relative progressivity (at the minimum, taxes should not be regressive). ${ }^{71}$ The CEQ uses the same convention.

${ }^{70}$ If a transfer is progressive (regressive) in absolute (relative) terms, it follows by definition that it must be progressive (regressive) in relative (absolute) terms, but the converse is not true. If a tax is progressive (regressive) in relative (absolute) terms, it follows by definition that it must be progressive (regressive) in absolute (relative) terms. However, the converse is not true.

${ }^{71}$ See Lambert (2002). 
Table 2 - Definitions of Progressivity of Taxes and Transfers

\begin{tabular}{|c|c|c|c|c|}
\hline & \multicolumn{2}{|c|}{ Taxes } & \multicolumn{2}{|c|}{ Transfers } \\
\hline & Relative & Absolute & Relative & $\begin{array}{c}\text { Absolute } \\
\text { (also called "pro-poor") }\end{array}$ \\
\hline 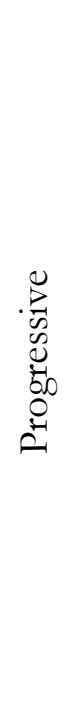 & $\begin{array}{l}\text { Poorer people pay } \\
\text { lower taxes in } \\
\text { relation to their } \\
\text { income. Post-fiscal } \\
\text { income is more equal } \\
\text { than market } \\
\text { income. }\end{array}$ & & $\begin{array}{l}\text { Poorer people get } \\
\text { larger transfers in } \\
\text { relation to their } \\
\text { income. Post-fiscal } \\
\text { income is more equal } \\
\text { than market income } \\
\text { but less equal than } \\
\text { when transfers are } \\
\text { also progressive in } \\
\text { absolute terms. }\end{array}$ & $\begin{array}{l}\text { Poorer people get } \\
\text { larger transfers in per } \\
\text { capita terms. Post- } \\
\text { fiscal income is more } \\
\text { equal than market } \\
\text { income and than when } \\
\text { transfers are } \\
\text { progressive in relative } \\
\text { terms. } \\
\text { If transfers are } \\
\text { progressive in absolute } \\
\text { terms, by definition they } \\
\text { are progressive in } \\
\text { relative terms. The } \\
\text { converse is not true. }\end{array}$ \\
\hline 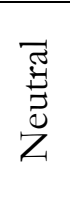 & \multicolumn{2}{|c|}{$\begin{array}{l}\text { Everyone pays the same proportion of } \\
\text { taxes in relation to their income. Market } \\
\text { income and post-fiscal income } \\
\text { distributions are the same. }\end{array}$} & \multicolumn{2}{|c|}{$\begin{array}{l}\text { Everyone receives the same proportion of } \\
\text { transfers in relation to their income. Market } \\
\text { and post-fiscal income distributions are the } \\
\text { same. }\end{array}$} \\
\hline 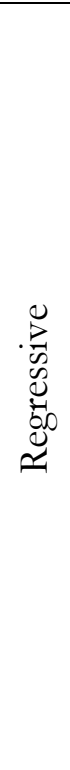 & $\begin{array}{l}\text { Poorer people pay } \\
\text { more taxes in } \\
\text { relation to their } \\
\text { income. Post-fiscal } \\
\text { income is more } \\
\text { unequal than market } \\
\text { income but less } \\
\text { unequal than when } \\
\text { taxes are regressive } \\
\text { in absolute terms. }\end{array}$ & $\begin{array}{l}\text { Poorer people pay } \\
\text { more taxes in per } \\
\text { capita terms. Post- } \\
\text { fiscal income is more } \\
\text { unequal than market } \\
\text { income and more } \\
\text { unequal than when } \\
\text { taxes are regressive } \\
\text { in only relative } \\
\text { terms. } \\
\text { If taxes are regressive } \\
\text { in absolute terms, by } \\
\text { definition they are } \\
\text { regressive in relative } \\
\text { terms. The converse is } \\
\text { not true. }\end{array}$ & $\begin{array}{l}\text { Poorer people get } \\
\text { smaller transfers in } \\
\text { relation to their } \\
\text { income. Post-fiscal } \\
\text { income is more unequal } \\
\text { than market income. }\end{array}$ & \\
\hline
\end{tabular}


Figure 5 - Lorenz Curves for Progressive and Regressive Transfers

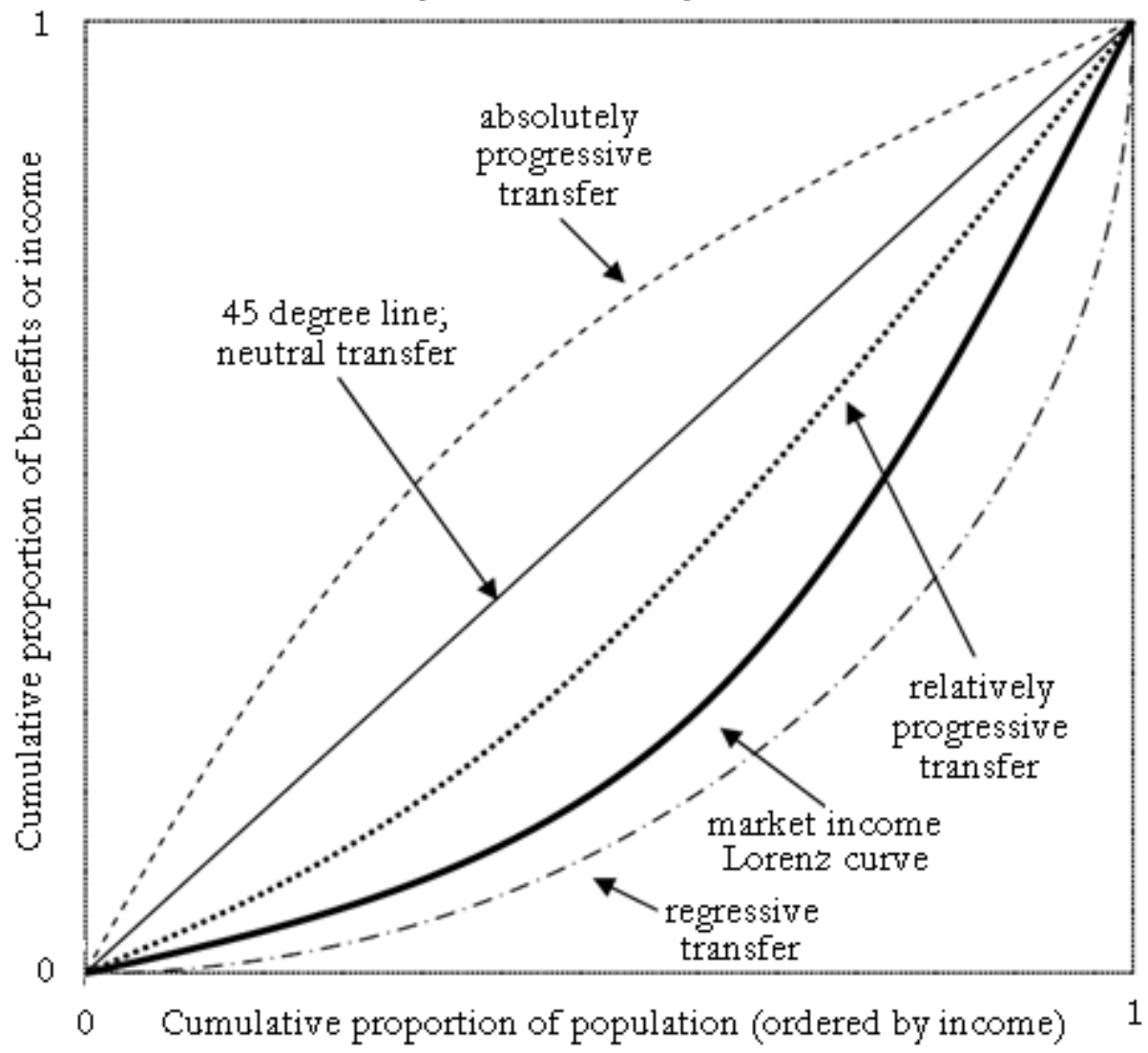

\section{Technical Definitions of Variables and Indicators}

\section{DEFINITIONS}

\section{Definitions of income}

NOTE: All the income variables will have to be calculated in per capita and per adult equivalent units as defined below.

Per capita bousebold income $\left(y_{i}\right)$ and $\left(y_{i \text { equivalized }}\right)$

For each definition of income below, individual $i$ 's per capita income $y_{i}$ should be calculated dividing household income by the number of members in the household and dividing household income by equivalized number of members using OECD equivalence scales (for comparability with other studies).

$y_{i}=\frac{\mathrm{Y}_{\mathrm{H}}}{\mathrm{M}}$

$y_{i \text { equivalized }}=\frac{\mathrm{Y}_{\mathrm{H}}}{1+0.5(\mathrm{~A}-1)+0.3 \mathrm{C}}$

where $\mathrm{Y}_{\mathrm{H}}$ is the income of the household, $\mathrm{M}$ is the number of members in the household, $\mathrm{A}$ is the number of adults in the household, and $\mathrm{C}$ is the number of children in the household.

1. Market income $\left(y^{m}\right)$ 
There are two ways that Market Income should be calculated (note that the two different calculations for market income will lead to two different calculations for each definition of income). The two calculations are: 1) Monetary: Earned plus unearned (monetary) market incomes before government taxes and transfers of any sort. It should include net private transfers, net remittances, and net alimony payments. 2) Total: Earned plus unearned market incomes (monetary and non-monetary) before government taxes and transfers of any sort. It should include net private transfers, net remittances, and net alimony payments AND imputed rent for owner-occupied housing and auto-consumption.

2. Net market income $\left(y^{n}\right)$

Market Income $y^{m}$ minus direct taxes and employee contributions to social security.

3. Disposable income $\left(y^{d}\right)$

Net market income $y^{m}$ plus direct monetary transfers.

4. Post-fiscal income $\left(y^{p f}\right)$

Disposable income $y^{d}$ plus indirect subsidies (including indirect tax expenditures) minus indirect taxes.

5. Final income $\left(y^{f}\right)$

Post-fiscal income $y^{p f}$ plus in-kind transfers minus in-kind taxes, co-payments and user costs. Whenever possible, a second estimate of final income should include participation costs such as opportunity cost of waiting in line, transportation costs, etc. (final income should be presented with and without the latter).

6. Final income* $\left(y^{* f}\right)$

Disposable income $y^{\mathrm{d}}$ plus in-kind transfers minus in-kind taxes, co-payments and user fees. Whenever possible, a second estimate of final income* should include participation costs such as opportunity cost of waiting in line, transportation costs, etc. (final income* should be presented with and without the latter).

\section{Definitions of Poverty Lines}

7. Income poverty line $(z)$

The standard international income poverty lines are \$2.50 PPP per day (per capita) for extreme poverty and \$4 PPP per day (per capita) for poverty. To convert these poverty lines into local currency poverty lines, the PPP conversion rate should be selected for the same year as the survey. If the PPP conversion rate is obtained from the World Development Indicators Databank, the series "PPP conversion factor, private consumption (LCU per international \$)". The monthly local currency poverty line is equal to the PPP per day poverty line times 30.42 (365 days per year/12 months per year) times the PPP conversion factor (of local currency units per PPP dollar).

A relative poverty line set at $50 \%$ of national median per capita disposable income should also be used to allow for comparability with the same figures calculated for advanced countries and national poverty lines.

If a national or official poverty line (or set of official regional poverty lines) is available, it should be used as well.

8. Education "Poverty Line" (Critical Level) 
The critical level of schooling is 12 years for upper middle income countries and 9 years for lower middle income countries. However, estimates should be done for both critical levels for comparability.

9. Health "Poverty Line" (Critical Level)

The critical level for health is a basic health insurance or package.

\section{Definitions of Macroeconomic Variables}

The macro indicators should be expressed in local currency. In addition, they should be from the same year in which the household surveys used to calculate poverty were conducted. Most can be obtained from the country's national accounts or from the World Development Indicators Databank (databank.worldbank.org). Please specify which source is used for each indicator. Include the hyperlink or a copy of the page where the information came from for verification purposes.

\section{Gross Domestic Product (GDP)}

If obtained from the World Development Indicators Databank, the series "GDP (current LCU)" should be used.

\section{Population (N)}

Population counts all residents regardless of legal status or citizenship--except for refugees not permanently settled in the country of asylum. If taken from the World Development Indicators Databank, the series "Population, total" should be used.

\section{Total government revenues}

Total government revenues include the total budgetary income of the federal government: tax and non-tax revenue plus income generated by direct budgetary controlled entities or public enterprises. In countries where revenue collected at the provincial or state level is important, the total should include the revenues obtained by governments at the subnational level if possible. Specify whether subnational revenue is included, and if so, include one figure with all revenues and one with only federal revenues (for comparability with other countries).

\section{Total government spending}

Total government spending according to public sector accounts. Write down specific definition of total government spending used in your study; specify when it is federal and subnational; when it includes current spending and public investment; when it is with or without employers' and employees' social security contributions.

\section{Social spending: total, disaggregated and social spending allocated to the poor}

Social spending according to public sector accounts should be expressed as a total and disaggregated into health, education, social security and social assistance. Furthermore, figures should be provided for spending on social security including employer/employee contributions and the non-contributory component only. Include the definitions used in your country for each category of social spending. For social spending allocated to poor, based on the definition of social spending, consider what is allocated to anti-poverty programs, basic education, basic health care, etc. as specified in the public sector budget. This may not be feasible in some countries. In addition, report the social spending allocated to the poor that is monetary only (not in-kind). Include definitions used in your country.

\section{Redistributive spending: total, disaggregated and redistributive spending allocated to the poor.}


Redistributive spending includes education, health, and social assistance plus indirect consumer subsidies (e.g., food, electricity and gasoline subsidies), some producer subsidies (e.g., agricultural producer subsidies), and "social" tax expenditures (exemption of VAT for some foodstuffs). The information on redistributive spending has to be teased out from public sector accounts at the federal level (and provincial level in the countries where study will include subnational government spending in the analysis). In some countries there is no information on other forms of redistributive spending; in such cases, one should confine the analysis to social spending. Redistributive spending should be expressed as a total and disaggregated into health, education, social security and social assistance. For redistributive spending allocated to poor, based on the definition of redistributive spending, consider what is allocated to anti-poverty programs, basic education, basic health care, etc. as specified in public sector budget. In addition, report the redistributive spending allocated to the poor that is monetary only (not in-kind). Include definitions used in your country.

\section{Definition of Net Transfers}

Net transfers equals transfers (subsidies) minus taxes (which could include co-payments, fees, etc.). Which transfers and taxes are included depends on the definition of income being used.

\section{Identifying Transfer Recipients}

\section{Direct Identification Method}

On some surveys, questions specifically ask if households received benefits from certain social programs, and how much they received. When this is the case, it is easy to identify transfer recipients and add or remove the value of the transfers from their income, depending on the definition of income being used.

\section{Inference Method}

Unfortunately, not all surveys have this information. In some cases, transfers from social programs are grouped with other income sources (in a category for "other income", for example). In this case, it might be possible to infer which families received a transfer based on the value they report in that income category.

\section{Simulation Method}

In the case that neither the direct identification nor the inference method can be used, transfer benefits should be simulated. For example, in the case of a conditional cash transfer that uses a proxy means test to identify eligible beneficiaries, one can replicate the proxy means test using survey data, identify eligible families, and simulate the program's impact. However, this method gives you the potential impact of transfers with perfect targeting and no errors of inclusion or exclusion. In order to correct for the overestimation of the incidence of benefits, you can use information on the errors of inclusion and exclusion estimated for other countries.

NOTE: It is very important to specify which transfer identification method you are using for each program AND to present results separately by method.

\section{BASIC INDICATORS}




\section{Income Poverty}

NOTE: Poverty gaps should be reported in local currency, and should be yearly. Calculations will have to be done using all the selected poverty lines and with income (and consumption when available) in both per capita terms and as equivalized income (definitions are above).

16. Before Net Transfers Income Poverty Gap or Market Income Poverty Gap $\left(P G^{m}\right)$

The sum of the distances between each poor person's market income $y^{m}$ and the income poverty line. Poor people are defined here as people whose market income $y^{m}$ is below the income poverty line $z$.

$P G^{m}=\sum_{i} z-y_{i}^{m}$ for $i=1, \ldots, Q^{m}$ and for all $y_{i}^{m}<z$

where $\mathrm{Q}^{\mathrm{m}}$ is the headcount of the market income poor (defined below).

17. After Direct Taxes Income Poverty Gap or Net Market Income Poverty Gap $\left(P G^{n}\right)$

The sum of the distances between each poor person's net market income $y^{n}$ and the income poverty line. Poor people are defined here as people whose net market income $y^{n}$ is below the income poverty line $z$.

$P G^{n}=\sum_{i} z-y_{i}^{n}$ for $i=1, \ldots, \mathrm{Q}^{\mathrm{n}}$ and for all $y_{i}^{n}<z$

where $\mathrm{Q}^{\mathrm{n}}$ is the headcount of the net market income poor (defined below).

18. After Direct Net Transfers Income Poverty Gap or Disposable Income Poverty Gap $\left(P G^{d}\right)$

The sum of the distances between each poor person's disposable income $y^{d}$ and the income poverty line. Poor people are defined here as people whose $y^{d}$ is below the income poverty line $Z$.

$P G^{d}=\sum_{i} z-y_{i}^{d}$ for $i=1, \ldots, \mathrm{Q}^{\mathrm{d}}$ and for all $y_{i}^{d}<z$

where $\mathrm{Q}^{\mathrm{d}}$ is the headcount of the disposable income poor (defined below).

19. After Direct and Indirect Net Transfers (Subsidies) Income Poverty Gap or Post-Fiscal Income Poverty Gap $\left(P G^{p f}\right)$

The sum of the distances between each poor person's post-fiscal income $y^{p f}$ and the income poverty line. Poor people are defined here as people whose $y^{p f}$ is below the income poverty line $z$.

$P G^{p f}=\sum_{i} z-y_{i}^{p f}$ for $i=1, \ldots, \mathrm{Q}^{\mathrm{pf}}$ and for all $y_{i}^{p f}<z$ where $\mathrm{Q}^{\mathrm{pf}}$ is the headcount of the post-fiscal income poor (defined below).

20. After Direct, Indirect and In-kind Net Transfers Income Poverty Gap or Final Income Poverty Gap (PG $\left.{ }^{f}\right)$

The sum of the distances between each poor person's per capita final income $y^{f}$ and the income poverty line. Poor people are defined here as people whose $y^{f}$ is below the income poverty line $z$.

$P G^{f}=\sum_{i} z-y_{i}^{f}$ for $i=1, \ldots, \mathrm{Q}^{\mathrm{f}}$ and for all $y_{i}^{f}<z$

where $\mathrm{Q}^{\mathrm{f}}$ is the headcount of the final income poor (defined below).

21. After Direct and In-kind Net Transfers Income Poverty Gap or Final Income* Poverty Gap $\left(P G^{* f}\right)$

The sum of the distances between each poor person's final income* $y^{* f}$ and the income poverty line. Poor people are defined here as people whose $y^{* f}$ is below the income poverty line $z$. 
$P G^{* f}=\sum_{i} z-y_{i}^{* f}$ for $i=1, \ldots, \mathrm{Q}^{* \mathrm{f}}$ and for all $y_{i}^{* f}<z$

where $\mathrm{Q}^{* \mathrm{f}}$ is the headcount of the final income poor (defined below).

22. Headcount of the Income Poor $\left(\mathrm{Q}^{j}\right)$

The number of people whose per capita income $y_{i}$ is less than the poverty line $z$. Multiple headcounts should be calculated, using each definition of income and different poverty lines (see above). The superscript $\mathbf{j}$ refers to each definition of income.

23. Income Poverty Headcount Index $\left(\mathrm{P}_{0}^{j}\right)$

The number of people whose per capita income $\mathrm{y}_{i}$ is less than the poverty line $z$, expressed as a percentage of the total population. Multiple headcount indices should be calculated, using each definition of income and different poverty lines (see above). The superscript $\mathbf{j}$ refers to each definition of income.

$\mathrm{P}_{0}^{j}=\frac{\mathrm{Q}^{j}}{\mathrm{~N}}$

where $\mathrm{N}$ is the total population (defined under Macroeconomic variables).

24. Income Poverty Gap Ratio $\left(\mathrm{P}_{1}^{j}\right)$

The sum of the distances between each poor person's income and the poverty line, divided by total population and expressed as a percentage of the poverty line. Multiple poverty gap ratios should be calculated, using each definition of income and different poverty lines (see above). The superscript $\mathbf{j}$ refers to each definition of income.

$\mathrm{P}_{1}^{j}=\frac{1}{\mathrm{~N}} \sum_{i=1}^{\mathrm{N}}\left(\frac{\mathrm{z}-\mathrm{y}_{i}}{\mathrm{z}}\right)$

where $\mathrm{N}$ is the total population and $\mathrm{z}-y_{i}$ takes a value of 0 when $\mathrm{y}_{i} \geq \mathrm{z}$.

25. Squared Income Poverty Gap Ratio $\left(P_{2}^{j}\right)$

The sum of the squared distances between each poor person's income and the poverty line, divided by total population and expressed as a percentage of the poverty line. This indicator takes the distribution of income among the poor into account by weighting the distance that each poor person's income is below the poverty line. Multiple squared poverty gap ratios should be calculated, using each definition of income and different poverty lines (see above). The superscript $\mathbf{j}$ refers to each definition of income.

$\mathrm{P}_{2}^{j}=\frac{1}{\mathrm{~N}} \sum_{i=1}^{\mathrm{N}}\left(\frac{\mathrm{z}-\mathrm{y}_{i}}{\mathrm{z}}\right)^{2}$

where $\mathrm{N}$ is the total population and $\mathrm{z}-\mathrm{y}_{i}$ takes a value of 0 when $\mathrm{y}_{i} \geq \mathrm{z}$.

NOTE: The Income Poverty Headcount Index, Income Poverty Gap Ratio, and Squared Income Poverty Gap Ratio should also be calculated before and after transfers (using market and final income) for the following subgroups of the poor: male-headed vs. female-headed households, age of household head (grouped as less than 25 years old, 25-40, 41-64, 65 or more), different racial or ethnic groups, urban vs. rural households, etc. These calculations only need to be performed using income per capita (without equivalence scales) using the $\$ 2.50$ and $\$ 4$ PPP per day poverty lines.

\section{Human Capital}

26. Total Demand for Education Coverage Among the Market Income Poor $\left(E G^{b t}\right)$

Calculated by multiplying the number of children in poor households times the relevant cost (public spending) per student (taking into account the different costs by level) plus the required demand-side subsidies to keep children in school. Children are defined as 
individuals between 6 and 18 years old (inclusive) and poor children are defined as children who live in households whose per capita market income $\mathrm{y}^{\mathrm{m}}$ is below the corresponding poverty line $\mathrm{z}$. Poor children who have already achieved the critical level of schooling are not included in the calculation. The critical level of schooling is 12 years for upper middle income countries and 9 years for lower middle income countries but calculations should be done for both for comparability purposes. Information should be presented for the whole "gap" but also by the number of children in the relevant age group and the average per capita cost by level.

$\mathrm{EG}^{\mathrm{bt}}=\sum_{l}\left[\frac{\text { Public spending on education at level } l}{\mathrm{~N}_{l}}\left(\mathrm{Q}_{l}\right)+\right.$ (required subsidy per poor student at level $\left.\left.l \times \mathrm{Q}_{l}\right)\right]$ where $\mathrm{N}_{l}$ is the total number of students at level $l(l=$ primary, lower secondary, secondary, tertiary) and $Q_{l}$ is the total number of poor school age children at level $l$

27. Total Demand for Health Coverage Among the Market Income Poor $\left(H G^{b t}\right)$

Calculated by imputing the cost of providing a standard health package to all the market income poor. Equivalently, the cost of a basic health insurance or package per insured person times the headcount of the market income poor.

$\mathrm{HG}^{\mathrm{bt}}=($ Total cost of basic health insurance package per insured person $) \times \mathrm{Q}^{\mathrm{m}}$

28. Before Net Transfers Human Capital Gap $\left(H K G^{b t}\right)$

The sum of the total demand for education coverage among the market income poor and the total demand for health coverage among the market income poor.

$\mathrm{HKG}^{\mathrm{bt}}=\mathrm{EG}^{\mathrm{bt}}+\mathrm{HG}^{\mathrm{bt}}$

29. After Net Transfers Education Coverage Gap (EG)

The before transfers Education Coverage Gap minus actual education spending on the market income poor by level (defined below)

$\mathrm{EG}=\mathrm{EG}^{\mathrm{bt}}-\mathrm{ESP}$

30. Actual Education Spending on the Market Income Poor (ESP)

Calculated using standard benefit incidence analysis, by multiplying the number of children in poor households attending public school times the relevant cost (public spending) per student plus the actual demand-side subsidies given to poor households, all by level.

31. After Net Transfers Health Coverage Gap (HG)

The before net transfers Health Coverage Gap minus actual government health spending on the market income poor (defined below).

$\mathrm{HG}=\mathrm{HG}^{\mathrm{bt}}-\mathrm{HSP}$

\section{Actual Health Spending on the Market Income Poor (HSP)}

Calculated using standard benefit incidence analysis: that is, imputing the amount of government subsidized health-related goods and services received by all the market income poor. "Received" will be measured two ways: by use of services and by rights of access to health services. The former is calculated as follows: the number of households who report using the contributory or non-contributory public health services at least once times the cost of the basic health package. The latter is calculated by multiplying the number of households who are covered by contributory or non-contributory public health services times the cost of the basic health package.

33. After Net Transfers Human Capital Gap ( $H K G)$

The sum of the after net transfers education coverage gap and the after net transfers health coverage gap.

$\mathrm{HKG}=\mathrm{EG}+\mathrm{HG}$ 


\section{Overall Poverty}

\section{Before Transfers Overall Poverty Gap $\left(O P G^{b t}\right)$}

The sum of the Before Net Transfers Income Poverty Gap and the Before Net Transfers Human Capital Gap $\mathrm{OPG}^{\mathrm{bt}}=\mathrm{PG}^{\mathrm{bt}}+\mathrm{HKG}^{\mathrm{bt}}$

\section{After Transfers Overall Poverty Gap (OPG)}

The sum of the After Net Transfers Income Poverty Gap and the After Net Transfers Human Capital Gap. Multiple After Transfers Overall Poverty Gaps should be calculated, using each of the definitions of income (except market income) and selected poverty lines (see above).

$\mathrm{OPG}=\mathrm{PG}+\mathrm{HKG}$

\section{Multi-dimensional Poverty Index}

Based on Alkire and Santos (2010), for a household to be considered deprived in the dimension of education, (e) three criteria will be used: i) if the household head has failed to complete 12 or 9 years of schooling in upper-middle and lower-middle income countries, respectively; ii) if all members of school-age are not enrolled; and iii) if at least one adult member has not completed the minimum required level of education for their age. In the case of health (b), a household will be deprived in this dimension if the head does not have access to medical services from either the public or the private sector. This is justified assuming that benefits are extended to the other household members. Finally, for the dimension of income $(y)$, calculations will be based on the aforementioned poverty lines: $\$ 2.5$ and $\$ 4$ PPP a day (per capita), a relative poverty line, and the official poverty line in each country. In any case, a household will be considered deprived in this dimension if its per capita (or equivalized) income is at or below the monetary threshold (income poverty line).

The aggregation follows the class of indices proposed by Alkire and Santos (2010), expressed as:

$M_{\alpha}=\frac{1}{n d} \sum_{i=1}^{n} \sum_{j=1}^{d} w_{j} \cdot\left(1-\frac{x_{i j}}{z_{j}}\right)^{\alpha}$

$\alpha>0$ being a parameter of dimension-specific aversion to poverty; $x_{i j}$ the quantity of available dimensions $j$ for household $i$ (with $j=y, e, h$ ); $z_{j}$ the threshold for each dimension; $d$ the total number of dimensions; and $w_{j}$ the weight given to each dimension, such that $\sum_{j=1}^{d} w_{j}=d$. Each of the three components of education has equal weight within the education dimension, so if education as a whole has a $1 / 3$ weight, each of the three components will have a weight of $1 / 9$ of the index.

When $\alpha=0$, equation (1) yields the adjusted headcount ratio $\left(M_{0}=H A\right)$, which is the product of two measures: the multidimensional headcount ratio $(H=q / n)$, and the average deprivation share across the poor (namely breadth of deprivations) expressed as: $A=\sum_{i=1}^{n} c_{i} /(q d)$, with $n$ being the total population; $q$ the number of households deprived in $\gamma$ or more dimensions $d$, and $c_{i}$ the number of 
deprivations experienced by household $i .^{72}$ The variable $\gamma$ is the sum of weighted dimensions in which a household is deprived in order to be considered multidimensionally poor (i.e. the $i^{\text {th }}$ household will be multidimensionally poor if $c_{i} \geq \gamma$, and non-poor otherwise). Notice that as $\gamma$ goes up, the number of multidimensionally poor households goes down, but the breadth of deprivations in these households goes up.

This methodology evaluates economic and human capital indicators individually using a between dimensions weighting system (i.e. the relative weight of income, health and education). Regarding the definition of weights, it is proposed to use equal weights assuming that no dimension is more important than another.

Overall, households will be identified as multidimensionally poor by counting the number of dimensions for which $x_{i j}<z_{j}$ (i.e. counting the number of deprivations) and then checking whether this number $\left(c_{i}\right)$ is equal to or exceeds the cut-off $\gamma$, say 1 out of 3 dimensions, 2 out of 3 dimensions, or 3 out of 3 dimensions. Notice that this procedure indicates that each of the dimensions is receiving equal weighting $(1 / 3$ each, with the education dimension being the weighted sum of its three components). Formally, $w_{i}=1$ for all $j=1, \ldots, d$, and therefore the identification threshold goes from $\gamma=1$ to $\gamma=d$.

If a country has adopted a multi-dimensional poverty index in its official reporting (e.g., Mexico), the index should be calculated with the methodology utilized by the country as well.

\section{Inequality}

36. Market Income Gini (Gini $\left.{ }^{\mathrm{m}}\right)$

Graphically, the market income Gini is represented by the area between the market income Lorenz curve and the line of equality. The market income Lorenz curve maps the cumulative share of market income on the vertical axis against the distribution of the population on the horizontal axis.

$$
\mathrm{Gini}^{\mathrm{m}}=2 \int_{0}^{1}(p-\mathrm{L}(p)) d p
$$

where $p$ is the cumulative proportion of the total population when individuals are ordered in increasing income values using market income (graphically, $p$ is also equivalent to the line of perfect equality) and $\mathrm{L}(p)$ is the Lorenz curve.

37. Net Market Income Gini (Gini ${ }^{\mathrm{n}}$ )

Net Market Income Gini should be calculated by the same method as above, using market income to construct the Lorenz curve.

38. Disposable Income Gini (Gini ${ }^{\mathrm{d}}$ )

Disposable Income Gini should be calculated by the same method as above, using disposable income to construct the Lorenz curve.

\footnotetext{
${ }^{72}$ When $\alpha=1$, equation (1) yields the adjusted poverty gap, defined as the weighted sum of dimension-specific poverty gaps; and when $\alpha=2$ it yields the adjusted squared poverty gap, defined as the weighted sum of the dimension-specific squared poverty gaps.
} 
39. Post-fiscal Income Gini (Gini ${ }^{\mathrm{pf}}$ )

Post-fiscal Income Gini should be calculated by the same method as above, using post-fiscal income to construct the Lorenz curve.

40. Final Income Gini (Ginif $)$

Final Income Gini should be calculated by the same method as above, using final income to construct the Lorenz curve.

41. Final Income* Gini (Gini*f)

Final Income* Gini should be calculated by the same method as above, using final income* to construct the Lorenz curve.

42. Other Inequality Measures

Also include calculations for the Theil index, 90/10, by deciles, etc.

\section{Concentration Curves}

Plot Lorenz curves for each definition of income but with households ranked by market income on the horizontal axis.

\section{Fiscal (Tax and Benefits) Incidence Curves}

Plot before transfers (using market income) and after transfers (using each of the other definitions of income) incidence curves by percentile and/or twentieth-tiles.

\section{Government Effort - NOTE: In order to ensure comparability among countries these} benchmark regressions are provided by the author; DO NOT estimate them

43. Government Revenue Effort (GRE)

Government revenue effort is calculated by performing ordinary least squares (OLS) regressions of log GDP per capita (PPP) against total government revenues as a percent of GDP of all countries for which data is available. The country's government revenue effort is equal to two times its residual value (actual value minus predicted value) divided by the standard deviation of the residual, plus five.

$\mathrm{GRE}=\left(2 \times \frac{\text { Residual value }}{S t d(\text { residual })}\right)+5$

44. Tax Collection Effort (TCE)

Tax collection effort is calculated by performing ordinary least squares (OLS) regressions of log GDP per capita (PPP) against total tax revenues as a percent of GDP of all countries for which data is available. The country's tax collection effort is equal to two times its residual value (actual value minus predicted value) divided by the standard deviation of the residual, plus five.

$\mathrm{TCE}=\left(2 \times \frac{\text { Residual value }}{\operatorname{Std}(\text { residual })}\right)+5$

45. Income Tax Collection Effort (ITCE)

Income tax collection effort is calculated by performing ordinary least squares (OLS) regressions of log GDP per capita (PPP) against tax revenues on income, profits, and capital gains as a percent of GDP of all countries for which data is available. The country's income tax collection effort is equal to two times its residual value (actual value minus predicted value) divided by the standard deviation of the residual, plus five. 
ITCE $=\left(2 \times \frac{\text { Residual value }}{S t d(\text { residual })}\right)+5$

46. Wealth Tax Collection Effort (WTCE) (the available)

Wealth tax collection effort is calculated by performing ordinary least squares (OLS) regressions of log GDP per capita (PPP) against tax revenues on property as a percent of GDP of all countries for which data is available. The country's wealth tax collection effort is equal to two times its residual value (actual value minus predicted value) divided by the standard deviation of the residual, plus five.

$\mathrm{WTCE}=\left(2 \times \frac{\text { Residual value }}{\operatorname{Std}(\text { residual })}\right)+5$

Note: the necessary data is currently not available to calculate the WTCE.

47. Government Spending Effort (GSE)

Government spending effort is calculated by performing ordinary least squares (OLS) regressions of log GDP per capita (PPP) against government spending as a percent of GDP of all countries for which data is available. The country's government spending effort is equal to two times its residual value (actual value minus predicted value) divided by the standard deviation of the residual, plus five.

$\mathrm{GSE}=\left(2 \times \frac{\text { Residual value }}{\operatorname{Std}(\text { residual })}\right)+5$

48. Social Spending Effort (SSE)

Social spending effort is calculated by performing ordinary least squares (OLS) regressions of $\log$ GDP per capita (PPP) against social spending as a percent of GDP of all countries for which IMF data is available. The country's social spending effort is equal to two times its residual value (actual value minus predicted value) divided by the standard deviation of the residual, plus five.

$\mathrm{SSE}=\left(2 \times \frac{\text { Residual value }}{\operatorname{Std}(\text { residual })}\right)+5$

\section{DEFINITIONS FOR QUESTIONNAIRE}

\section{Resources}

R1.1

Sufficient combined resources

Combined resources collected by the government is sufficient to close a poverty gap if its

$\mathrm{R} 1.2$

value is strictly larger than the value of the poverty gap.

\section{Consistent}

Total revenues are consistent with the country's GDP per capita if the government revenue effort (GRE) (defined under the "Government Effort" section of Basic Indicators) is greater than 5. Tax revenues are consistent with the country's GDP per capita if the tax collection

\section{$\mathrm{R} 1.3$} effort (TCE) (defined under "Basic Indicators") is greater than 5.

Low per capita income

Latin American countries that are lower-middle or low income can be classified as having R2.1 low per capita income if they have 2009 GDP per capita of less than $\$ 4000$ PPP per year. 
Sufficient (resources allocated to redistributive spending)

Redistributive spending is potentially sufficient to close the poverty gap if its value is strictly

$\mathrm{R} 2.2$

larger than the value of the poverty gap.

Consistent

Government spending is consistent with the country's GDP per capita if the government spending effort (GSE) (defined under "Basic Indicators") is greater than 5. Social spending is consistent with the country's GDP per capita if the social spending effort (SSE) (defined under "Basic Indicators") is greater than 5.

R2.3

High military spending

According to the Stockholm International Peace Research Institute (SIPRI), high military spending is defined as military spending greater than $4 \%$ of GDP.

NOTE: we do not provide figures that might serve as a benchmark for large subsidies to other sectors, overblown administration, or a large debt burden; it will be up to the country experts to determine if these factors might explain why the government does not allocate sufficient resources to redistributive spending.

\section{Equity}

E1.

Sufficient (proportion of redistributive spending allocated to closing the before net transfers poverty gaps)

The proportion of redistributive spending allocated to closing the before net transfers

poverty gaps is potentially sufficient to close the poverty gap if its value is strictly larger than

E2.1

the value of each poverty gap.

Too large (net transfers to the non-poor)

Net transfers to the non-poor are too large if total net transfers is sufficient to close the poverty gap but total net transfers allocated to the poor is not.

E2.2

Quantiles

Quantiles ideally should be centiles. If that is not feasible, twentieth-tiles, deciles or quintiles can be used.

Suits index $x^{73}$

The Suits index is a concentration coefficient for taxes. First, a tax concentration curve is constructed, with cumulative share of taxes paid on the vertical axis and cumulative share of market income on the horizontal axis. Graphically, the Suits index is twice the area between the line of equality (which can also be interpreted as the line of tax neutrality) and the tax concentration curve. If the tax concentration curve lies above the line of equality, the Suits index will be negative, which indicates that taxes are progressive in absolute terms.

$$
\mathrm{S}=2 \int_{0}^{1}(p-h(p)) d p
$$

\footnotetext{
${ }^{73}$ See Suits (1977).
} 
where $p$ is the cumulative proportion of total population when individuals are ordered in increasing income values using market income (graphically, $p$ is also equivalent to the line of perfect equality) and $h(p)$ is the tax concentration curve.

Kakwani index ${ }^{74}$

Graphically, the Kakwani index is twice the area between the market income Lorenz curve and the tax concentration curve. If the tax concentration curve is above the Lorenz curve, the Kakwani index will be negative, which indicates that taxes are regressive in relative terms. Equivalently, the Kakwani index can be calculated as the Suits Index minus the market income Gini. If market income is not available, use the net market income Gini.

Middle range

Kakwani $=$ Suits - Gini $^{\mathrm{m}}$

The boundaries for middle range should be given by the non-poor that are not in the top 10 percent.

Progressive in absolute terms (programs and policies)

Poorer people get larger transfers in per capita terms. Post-fiscal income is more equal than market income and than when transfers are progressive in only relative terms. Note: if transfers are progressive in absolute terms, by definition they are progressive in relative terms. The converse is not true.

Progressive in relative terms (programs and policies)

Poorer people get larger transfers in relation to their income. Post-fiscal income is more equal than market income but less equal than when transfers are progressive in only absolute terms.

Neutral (programs and policies)

Everyone receives the same proportion of transfers in relation to their income. Market income and post-fiscal income distributions are the same.

Regressive (programs and policies)

Poorer people get smaller transfers in relation to their income. Post-fiscal income is more unequal than market income.

Consistent

Income tax revenues are consistent with the country's GDP per capita if the income tax collection effort ITCE (defined under "Basic Indicators") is greater than 5. Taxes on wealth are consistent with the country's GDP per capita if the wealth tax collection effort WTCE (defined under "Basic Indicators") is greater than 5 .

Progressive (taxes)

Poorer people pay less taxes in relation to their income. Post-fiscal income is more equal than market income.

Neutral (taxes)

Everyone pays the same proportion of taxes in relation to their income. Market income and post-fiscal income distributions are the same.

Regressive in absolute terms (taxes)

Poorer people pay more taxes in per capita terms. Post-fiscal income is more unequal than market income and more unequal than when taxes are regressive in only relative terms.

${ }^{74}$ See Kakwani (1977). 
Note: if taxes are regressive in absolute terms, by definition they must be regressive in relative terms.

Regressive in relative terms (taxes)

Poorer people pay more in taxes in relation to their income. Post-fiscal income is more unequal than market income but less unequal than when taxes are regressive in absolute terms.

Impact on inequality

The impact of each program or policy on inequality is measured as its impact on the market income Gini, independent of the other programs (i.e., the impact of each individual program assumes the other programs do not exist). Calculate the Gini (and other inequality measures) using market income plus transfers from one program or policy. The market Gini after program $j$ should be recorded, as well as the percent reduction in the Gini caused by the program:

Impact $=\frac{\text { Gini }^{\mathrm{m}}-\mathrm{Gini}_{\text {after program } \mathrm{j}}^{\mathrm{m}}}{\text { Gini }^{\mathrm{m}}}$

This should be done for each flagship program or policy, always beginning with market income and only removing the transfers from one program. The combined impact must be calculated the same way, by calculating the Gini using market income plus combined transfers from the flagship programs and policies. NOTE that the combined impact is not equal to the sum of their impacts or the sum of the percentage point Gini reductions caused by each program.

Simulated impact on inequality

The simulated impact of each program is measured as its impact on the market income Gini, independent of the other programs (i.e., the impact of each individual program assumes the other programs do not exist). Simulate the impact of one program or policy by assuming that it has perfect targeting (no leakages to non-eligible households) and complete coverage of the target population (all eligible families receive the appropriate transfer) according to the program's eligibility rules. The market Gini after program $j$ should be recorded, as well as the percent reduction in the Gini caused by the program:

Simulated impact $=\frac{\mathrm{Gini}^{\mathrm{m}}-\mathrm{Gini}_{\mathrm{after} \text { simulation of program } \mathrm{j} \text { with perfect coverage and targeting }}^{\mathrm{m}}}{\mathrm{Gini}^{\mathrm{m}}}$

This should be done for each flagship program or policy, always beginning with market income and only removing the transfers from one program. The combined simulated impact must be calculated the same way, by calculating the Gini using market income plus simulated combined transfers from the flagship programs and policies, assuming perfect coverage and targeting. NOTE that the combined simulated impact is not equal to the sum of their simulated impacts or the sum of the percentage point Gini reductions caused by each simulated program.

E3.1

Redistributive programs and policies

Examples of programs: conditional or unconditional cash transfer programs; workfare or employment (or employment guarantee) programs; programs to protect poor households from the financial impact of illness, disability or death; programs to provide noncontributory health insurance; programs to prevent people from falling into poverty during old age; programs or policies specifically addressed to building human capital and assets of the poor; early childhood development programs for poor children; programs for pregnant 
and lactating poor women; programs for poor youth at risk; programs to increase school attendance of the poor (e.g., scholarships, school feeding programs, CCTs); programs to improve the poor's nutrition and health (e.g., food coupons, subsidized basic foodstuffs, nutritional supplements, etc.); programs to improve the poor's access to housing; programs to improve the poor's access to energy (e.g., differential prices); programs to improve the poor's access to credit and private insurance; programs to empower the poor; programs to reduce social exclusion and discrimination; programs to support/empower ethnic minorities; programs to empower women; programs to achieve other socially desirable objectives. Examples of policies: tax systems, public education systems, public health systems, pension systems, price subsidies, price support systems, subsidies to specific sectors (e.g., agriculture).

\section{Coverage rate among the poor}

The percentage of the poor that are covered by the specific programs and overall.

Equivalently, number of covered poor divided by total number of poor.

Coverage rate among relevant sub-groups

The percentage of members of each sub-group that are covered by the specific program.

Equivalently, the number of covered members of the sub-group divided by the total number of members of the sub-group. Note that all members of the sub-group are poor by definition.

E3.2

Safety nets

Examples of targeted safety net programs include cash transfers, food stamps, school feeding programs, food-for-work, and food distribution programs.

E3.4

More likely to be poor

Estimate a probit regression to predict the probability of being poor before net transfers (using market income), using only the household heads as observations. Possible independent variables include geographical region, gender, marital status, educational attainment, age, race, number of children (or a dummy variable equal to 1 if the household has children), precarious location (i.e. a dummy variable equal to 1 if living in a shantytown), and urban/rural. Please specify how the variables are defined (i.e. how urban and rural areas are defined).

More likely to be excluded

Estimate a probit regression to predict the probability of being poor after net transfers

E3.5

(using final income) conditional on being poor before net transfers.

Impact on the headcount index, poverty gap ratio, and squared poverty gap ratio

See the instructions for calculating the impact on inequality above, and replace Gini $^{\mathrm{m}}$ with $\mathrm{P}_{0}^{m}, \mathrm{P}_{1}^{m}$, and $\mathrm{P}_{2}^{m}$.

Simulated impact on the headcount index, poverty gap ratio, and squared poverty gap ratio

See the instructions for calculating the simulated impact on inequality above, and replace Gini ${ }^{\mathrm{m}}$ with $\mathrm{P}_{0}^{m}, \mathrm{P}_{1}^{m}$, and $\mathrm{P}_{2}^{m}$.

E4.1

Average Poverty Gap (APG)

The average poverty gap is equal to the Before Net Transfers Income Poverty Gap divided by the number of market income poor. 


\section{E5.1}

$$
\mathrm{APG}=\frac{\mathrm{PG}^{\mathrm{m}}}{\mathrm{Q}^{\mathrm{m}}}
$$

\section{Squared After Net Transfers Poverty Gap Ratio $\left(\mathrm{P}_{2}^{j}\right)$}

The Squared Income Poverty Gap, defined under "Poverty" in "Basic Indicators". Here, the after-transfers Squared Income Poverty Gap Ratio refers to $\mathrm{P}_{2}^{j}$ when $j=n, d, p f, f, f^{*}$

\section{Quality}

Q1.2

Non-distortionary taxes

Taxes that do not prevent market efficiency by creating distortions or externalities in the market.

Excess revenue from exceptional conditions such as commodity price booms or proceeds

Q1.3 from privatization.

\section{Counter-cyclical policies}

Policies intended to counteract income volatility resulting from idiosyncratic or systemic shocks.

Q2.5

Independent evaluations

Evaluations that are not carried out by the government. Ideally, these evaluations should be carried out by academics.

International standards for quality of social services

This could be measured using PISA (Programme for International Student Assessment) and

SERCE (Second Regional Comparative and Explanatory Study).

Exit strategy

Process under which a program has a plan to help the beneficiaries escape poverty and no longer receive benefits from the program.

\section{Accountability}

\section{A1.1}

Credible mechanisms for external validation

Credible mechanisms for external validation could include academics, independent national organizations, or international organizations such as the Socio-Economic Database on Latin America and the Caribbean (SEDLAC), the United Nations' Economic Commission on Latin America and the Caribbean (ECLAC), or the World Bank.

\section{A2.1}

\section{International standard for metadata documentation}

International standards for metadata documentation can be measured using the Accelerated Data Program, established by PARIS21, World Bank, and others (2009), or the Special Data Dissemination Standard established by the International Monetary Fund. 


\section{References}

Adcock, Robert and David Collier. Sep 2001. "Measurement Validity: A Shared Standard for Qualitative and Quantitative Research.” The American Political Science Review 95(3): 529-546.

Adema, Willem and Maxime Ladaique. 2005. "Net Social Expenditure, 2005 Edition: More Comprehensive Measures of Social Support." OECD Social, Employment and Migration Working Papers 29.

Aghion, Philippe, Christopher Harris and John Vickers. Apr 1997. "Paper and Proceedings of the Eleventh Annual Congress of the European Economic Association." European Economic Review 41(35): 771-782.

Aghion, Philippe and Peter Howitt. Mar 1992. "A Model of Growth through Creative Destruction." Econometrica 60(2): 323-51.

Alkire, Sabina and Maria Emma Santos. 2010. "Acute Multidimensional Poverty: A New Index for Developing Countries.” OPHI Working Paper No. 38, Oxford University, July 2010.

Alkire, Sabina and James Foster. Dec 2009. "Counting and Multidimensional Poverty Measurement." OPHI Working Paper No. 32. Oxford: Oxford Poverty \& Human Development Initiative, Oxford Department of International Development, Queen Elizabeth House, University of Oxford.

Atkinson, Anthony B. 1983. Social Justice and Public Policy. MIT Press.

Barr, Nicholas. 2004. Economics of the Welfare State: Fourth Edition. New York: Oxford University Press.

Barros, Ricardo, Mirela de Carvalho, and Samuel Franco. 2007. "O papel das Transferências Públicas na Queda Recente da Desigualdade de Renda Brasileira.” In Desigualdade de Renda no Brasil: uma análise da queda recente, ed. Ricardo Paes de Barros, Miguel Nathan Foguel and Gabriel Ulyssea, Chapter 16 Volume 2. Brasília: Instituto de Pesquisa Economica Aplicada.

Barros, Ricardo, Mirela de Carvalho, Samuel Franco, and Rosane Mendonça. 2010. "Markets, the State and the Dynamics of Inequality: Brazil's Case Study." In Declining Inequality in Latin America: A Decade of Progress?, ed. L. F. Lopez-Calva and N. Lustig. Washington DC: Brookings Institution Press.

Barros, Ricardo, Francisco Ferreira, Jose Molinas Vegas and Jaime Saavedra Chanduvi. 2009. Measuring Inequality of Opportunities in Latin America and the Caribbean. Washington DC: World Bank. Available online http:// siteresources.worldbank.org/BRAZILEXTN/Resources/3223401222953505624/BookHOI.pdf

Bergh, Andreas. Sep 2005. "On the counterfactual problem of welfare state research: How can we measure redistribution?” European Sociological Review 21 (4). 
Birdsall, Nancy, Augusto de la Torre and Rachel Menezes. 2008. Fair Growth: Economic Policies for Latin America's Poor and Middle-Income Majority. Washington DC: Brookings Institution Press.

Bourguignon, François and Luiz A. Pereira da Silva, eds. 2003. The Impact of Economic Poverty and Income Distribution. Washington DC: The World Bank.

Breceda, Karla, Jamele Rigolini and Jaime Saavedra. 2008. "Latin America and the Social Contract: Patterns of Social Spending and Taxation." Policy Research Working Paper 4604. World Bank Latin American and Caribbean Region Poverty Department Poverty Reduction and Economic Management Division. Washington DC: World Bank. Available online http://go.worldbank.org/BWBRP91A50

Chen, Shaohua and Martin Ravallion. 2008. "The developing world is poorer than we thought, but no less successful in the fight against poverty." Policy Research Working Paper 4703. World Bank Development Research Group. Washington DC: World Bank. Available online http://go.worldbank.org/BWBRP91A50

De Ferranti, David, Guillermo E. Perry, Francisco Ferreira and Michael Walton. 2004. Inequality in Latin America: Breaking with History? Washington DC: World Bank.

DeFina, Robert H. and Kishor Thanawala. 2004. "International Evidence on the Impact of Transfers and Taxes on Alternative Poverty Indexes.” Social Science Research 33: 322-338.

Dilnot Andrew, John Kay, and Michael Keen. 1990. "Allocating Taxes to Households: A Methodology." Oxford Working Papers 42 (1): 210-230.

Economic Commission for Latin America and the Caribbean (ECLAC). 2007. Social Panorama of Latin America, 2007. Santiago Chile: United Nations.

Esquivel, Gerardo, Nora Lustig, and John Scott. 2010. “A Decade of Falling Inequality in Mexico: Market Forces or State Action?" In Declining Inequality in Latin America: A Decade of Progress? ed. L. F. López-Calva and N. Lustig. Washington DC: Brookings Institution Press.

Ferreira, Francisco H.G. and David Robalino. May 2010. "Social Protection in Latin America: Achievements and Limitations.” Policy Research Working Paper 5305. Washington, DC: World Bank, Latin America and Caribbean Region Office of the Chief Economist, and Human Development Network Social Protection and Labor Unit. available online http:/ /wwwwds.worldbank.org/servlet/WDSContentServer/WDSP /IB/2010/05/10/000158349_20100510134942/Rendered/PDF/WPS5305.pdf

Fiszbein, Ariel and Norbert Schady with Francisco Ferreira, Margaret Grosh, Nial Kelleher, Pedro Olinto, and Emmanuel Skoufias. 2009. Conditional Cash Transfers: Reducing Present and Future Poverty. A World Bank Research Report. Washington DC: World Bank. 
. 2010. "Supplementary Webappendix: Financing of health systems to achieve the health Millennium Development Goals in low-income countries.” Lancet 375 (9715): 419-26.

Goñi, Edwin, J. Humberto López, and Luis Servén. 2008. "Fiscal Redistribution and Income Inequality in Latin America.” Policy Research Working Paper 4487. World Bank Development Research Group Macroeconomics and Growth Team. Washington DC: World Bank. Available online http://go.worldbank.org/BWBRP91A50

Grosh, Margaret, Carlo del Ninno, Emil Tesliuc, and Azedine Ouerghi. 2008. For Protection and Promotion: The Design and Implementation of Effective Safety Nets. Washington DC: World Bank. Available online

http://siteresources.worldbank.org/SAFETYNETSANDTRANSFERS/Resources/For_Protection _and_Promotion_complete.pdf

Hausmann, Ricardo, Bailey Klinger and Rodrigo Wagner. Sep 2008. "Doing Growth Diagnostics in Practice: A 'Mindbook"' CID Working Paper 77. Center for International Development at Harvard University.

Hausmann, Ricardo, Dani Rodrik and Andrés Velasco. Mar 2006. "Getting the Diagnosis Right: A New Approach to Economic Reform.” Finance and Development 43(1): 12-15.

Huber, Evelyne, François Nielsen, Jenny Pribble and John D. Stephens. Dec 2006. "Politics and Inequality in Latin America and the Caribbean." American Sociological Review 71(6):943-963.

Kakwani, N.C. 1977. "Measurement of Tax Progressivity: An International Comparison.” The Economic Journal 87(345): 71-80.

Lambert, Peter. 2002. The Distribution and Redistribution of Income: Third Edition. Manchester United Kingdom: Manchester University Press.

López-Calva, Luis F. and Nora Lustig. Eds. 2010. Declining Inequality in Latin America: A Decade of Progress? Washington DC: Brookings Institution Press.

López, Humberto. Jun 2006. "Did Growth Become Less Pro-Poor in the 1990s?” Policy Research Working Paper 3931. Washington DC: World Bank. Available online http://go.worldbank.org/BWBRP91A50

López, Humberto J. and Guillermo Perry. 2008. "Inequality in Latin America: Determinants and Consequences." Policy Research Working Paper 4504. World Bank Latin America and Caribbean Region Office of the Regional Chief Economist. Washington DC: World Bank. Available online http://go.worldbank.org/BWBRP91A50

Lora, Eduardo. Ed. 2006. The State of State Reforms in Latin America. Washington DC: World Bank. 
Lustig, Nora. 2000. "Crises and the Poor: Socially Responsible Macroeconomics." Economia: The Journal of the Latin American and Caribbean Economic Association 1(Fall 1): 1-45. Washington DC: Brookings Institution Press.

Mookherjee, Dilip and Debraj Ray. 2003. "Persistent Inequality." Review of Economic Studies 70(2): 369-93.

. 2006. "Occupational Diversity and Endogenous Inequality.” Working Paper. Institute for Economic Development. Boston MA: Boston University.

Morra Imas, Linda G. and Ray C. Rist. 2009. The Road to Results: Designing and Conducting Effective Development Evaluations. Washington DC: World Bank.

Narayan, Deepa,Robert Chambers, Meera K. Shah and Patti Petesch. 2000. Crying Out For Change. Voices of the Poor, Oxford University Press.

O’Donnell, Owen, Eddy van Doorslaer, Adam Wagstaff and Magnus Lindelow. "Analyzing Health Equity Using Household Survey Data: A Guide to Techniques and Their Implementation.” WBI Learning Resources Series. Washington, DC: The World Bank.

Organization for Economic Cooperation and Development (OECD) and The Development Centre. 2008. Latin American Economic Outlook 2009. Prepared by OECD Development Center Latin America and Caribbean Desk. Paris France: OECD.

Perry, Guillermo, Humberto López, Omar Arias, William Maloney, and Luis Servén. 2006. Poverty Reduction and Growth: Virtuous and Vicious Circles. Washington DC: World Bank.

Ravallion, Martin. 2008. "Bailing out the World's Poorest.” Policy Research Working Paper 4763. World Bank Development Research Group. Washington DC: World Bank. Available online http://go.worldbank.org/BWBRP91A50

Rodrik, Dani. 2007. One Economics, Many Recipes: Globalization, Institutions, and Economic Growth. Princeton: Princeton University Press.

Shah, Anwar. Ed. 2003. "Ensuring Accountability Where There is No Bottom Line." Handbook on Public Sector Performance Reviews 1. Washington DC: The World Bank.

Shah, Anwar. Ed. 2003. "Measuring Government Performance in the Delivery of Public Services." Handbook on Public Sector Performance Reviews 2. Washington DC: The World Bank.

Suits, Daniel B. Sep 1997. "Measure of Tax Progressivity." The American Economic Review 67 (4): 747 752.

United Nations Development Policy and Analysis Division. United Nations. Economic and social development. Department of Economic and Social Affairs. Divisions and offices. Development Policy 
and Analysis Division. Committee for Development Policy. Least Developed Countries Information found on website. http://www.un.org/esa/policy/devplan/profile/index.html

2007. MDG Monitor: Tracking the Millennium Development Goals. Available online http://www.mdgmonitor.org/

. 2010. The Human Development Index (HDI). Available online

http://hdr.undp.org/en/statistics/hdi/

Van de Walle, Dominique and Kimberly Nead (eds.). 1995. Public Spending and the Poor: Theory and

Evidence. Baltimore and London: Published for the World Bank by John Hopkins University Press.

Work Bank. 2000/2001. "World Development Report 2000/2001: Attacking Poverty." Washington, DC and New York: Published for the World Bank by Oxford University Press. Available online http://go.worldbank.org/7KWQQ1WVT0

. 2005. World Development Report 2006: Equity and Development. Washington DC: World Bank.

. 2006. "Country Policy and Institutional Assessments." Operations Policy and Country Services. Available online http:// siteresources.worldbank.org/IDA/Resources/CPIA2006Questionnaire.pdf . 2008b. World Development Indicators 2008. Washington DC: World Bank. CD-ROM.

. 2009a. Countries. Latin American and the Caribbean. Data and Statistics. Online Atlas of Millennium Development Goals (interactive map). Millennium Development Goal 1: Eradicate Extreme Poverty and Hunger. Poverty. Map of Countries according to the population that lives below $\$ 1.25$ a day (2005 estimates) found on website http://devdata.worldbank.org/atlas-mdg/es/

2009b. "The World Bank's Country Policy and Institutional Assessment, An Evaluation." Independent Evaluation Group. Washington, DC: World Bank. available online http://siteresources.worldbank.org/EXTCPIA/Resources/cpia_full.pdf

2011. "CPIA Public Sector Management and Institutions Cluster Average." available online http://data.worldbank.org/indicator/IQ.CPA.PUBS.XQ 